\title{
CEsifo WORKING

\section{Do Multinational Firms Use Tax Havens to the Detriment of Other Countries?}

Dhammika Dharmapala 


\section{Impressum:}

CESifo Working Papers

ISSN 2364-1428 (electronic version)

Publisher and distributor: Munich Society for the Promotion of Economic Research - CESifo

$\mathrm{GmbH}$

The international platform of Ludwigs-Maximilians University's Center for Economic Studies and the ifo Institute

Poschingerstr. 5, 81679 Munich, Germany

Telephone +49 (0)89 2180-2740, Telefax+49 (0)89 2180-17845, email office@cesifo.de

Editor: Clemens Fuest

https://www.cesifo.org/en/wp

An electronic version of the paper may be downloaded

- from the SSRN website: www.SSRN.com

- from the RePEc website: $\quad$ www.RePEc.org

- from the CESifo website: https://www.cesifo.org/en/wp 


\title{
Do Multinational Firms Use Tax Havens to the Detriment of Other Countries?
}

\begin{abstract}
The use of tax havens by multinational corporations (MNCs) has attracted increasing attention and scrutiny in recent years. This paper provides an exposition of the academic literature on this topic. It begins with an overview of the basic facts regarding MNCs' use of havens, which are consistent with the location of holding companies, intellectual property, and financial activities in havens. However, there is also evidence of significant frictions that limit MNCs' use of havens. These limits can be attributed to nontax frictions (such as the legal and business environment in different jurisdictions), to tax law provisions limiting profit shifting, and to the costs of tax planning. There is evidence consistent with the relevance of each of these channels. The paper also argues that nonhaven countries have available a range of powerful tax law instruments to neutralize the impact of MNCs' use of havens. To the extent that it is not due to political dysfunction, their failure to deploy these instruments more extensively can be viewed as a deliberate policy choice, attributable either to collective action problems among nonhavens or to the possibility that in certain circumstances MNCs' use of havens increases the welfare of nonhaven countries. In either case, MNCs' use of havens is facilitated in crucial respects by the laws of nonhaven countries. Finally, the paper discusses how the distinction commonly drawn in public finance theory between "tax avoidance" and "behavioral responses to taxation" can illuminate current debates about the magnitude and implications of MNCs' profit shifting to havens.
\end{abstract}

JEL-Codes: H250, F230.

Keywords: multinational firms, tax havens, international taxation, foreign direct investment, CFC rules, thin capitalization rules.

\author{
Dhammika Dharmapala \\ University of Chicago Law School / USA \\ dharmap@uchicago.edu
}

Revised Version: February 2020. First Version: July 2019

This paper was prepared as part of the Brookings Institution project on "Multinational Corporations in a Changing Global Economy.” I thank Fritz Foley, Jim Hines, David Wessel and participants at the authors' conferences at the Brookings Institution in December 2018 and December 2019 (especially my discussant Kim Clausing) for helpful comments. I also thank participants at the 2019 American Economic Association meetings in Atlanta for valuable comments on a presentation of some related ideas, and Johannes Becker, Thiess Büttner, Clemens Fuest, Jim Hines, Tom Horst, Li Liu, Ray Mataloni, and Gabriel Zucman for helpful conversations. I acknowledge the financial support of the Lee and Brena Freeman Faculty Research Fund at the University of Chicago Law School. Any remaining errors or omissions are my own. 


\section{1) Introduction}

The activities of multinational corporations (MNCs) in countries and territories that are widely described as tax havens has attracted growing public and academic attention in recent years. Tax haven activity appears to be an important component of MNCs' wider global operations. Thus, the topic is important to understanding the global activities of MNCs as well as the role of tax haven jurisdictions in the global economy. It also illuminates aspects of the wider process of global economic integration that is central to many policy debates and political developments in the current highly fraught global environment. This paper seeks to provide an exposition of the academic literature on this topic. It does not aim to be a comprehensive survey of the academic literature, although it covers a wide range of studies. It builds on prior surveys of the role of tax havens (e.g. Dharmapala, 2008; Hines, 2010) and of profit shifting by MNCs (e.g. Dharmapala, 2014a), but develops a largely distinct set of themes and arguments. It is aimed at a general audience of those interested in international economic issues, rather than at tax specialists. Admittedly, some tax law concepts are required to understand the topic; however, the paper aims to be largely self-contained in providing simple explanations of these concepts for a general audience.

The paper uses a pragmatic working definition of tax havens that corresponds to usage in the prior academic literature, without any judgmental intent. In particular, the definition used here is based on the list of tax havens constructed in Dharmapala and Hines (2009), with some minor updates described in Section 2 below. The term "other countries" in the title refers to all nonhavens, including (but not by any means limited to) the United States. Moreover, while most of the data and illustrations are drawn from US-based MNCs, the discussion seeks to be global in nature, applying to MNCs based in all countries. Because of its central importance to MNCs' haven use, Section 4 below discusses the evidence on profit shifting across jurisdictions by MNCs. However, this paper's primary focus is not on the analysis of firms' profit shifting activity (which is more fully addressed in Dharmapala (2014a) and in Dyreng and Hanlon (2019)), but rather on government policies that facilitate or restrict haven use and profit shifting, and why such policies are adopted.

Importantly, this paper focuses on MNCs' use of havens. Much of the public debate about havens tends to conflate the use of havens by MNCs with that by individual residents of nonhaven countries, and emphasizes the role of tax havens' secrecy. In general, these activities are quite 
distinct - MNCs' activities in havens are generally thought to be lawful (although MNCs' tax planning may involve adopting more or less aggressive positions in the face of legal uncertainty). In contrast, individuals' use of havens is typically unlawful and relies on secrecy (although the spread of information exchange among governments is arguably in the process of eliminating individual evasion via foreign financial accounts). Thus, this distinction corresponds quite closely to that between tax avoidance or tax planning (the lawful reduction of taxes owed) and tax evasion (the failure to pay legally-owed taxes). While tax haven secrecy and tax evasion have not generally been thought to be of much relevance for MNCs' tax haven activities, some nuances to this overall picture have been introduced by a recent literature (discussed in Section 2.3 below) that finds evidence that MNCs' haven activity may be responsive to information exchange and that secrecy may play some role in firms' haven activities. Section 2.3 seeks to place this new evidence within a broader conceptual framework (derived from Desai and Dharmapala (2006; 2008; 2009a, b; 2018)) that highlights the relationship between tax avoidance and agency costs.

The paper begins with a summary (in Section 2) of the most salient facts about MNCs' haven activities, drawing on the aggregate country-level data on the foreign operations of US MNCs provided by the Bureau of Economic Analysis (BEA) at the US Department of Commerce. This aggregate data reveals patterns of MNC activity that are highly consistent with the use of havens to a disproportionate extent (relative to indicators of "real" activity such as employment and tangible assets) for the location of holding companies within MNC groups, for the location of intangible assets, and for financing activities. However, an important caveat is that the system of accounting used by the BEA for foreign affiliates that serve as holding companies may lead to certain measures of the haven activity of MNCs (notably the fraction of income reported in havens) being substantially overstated. Notwithstanding this, the differences between haven and nonhaven affiliates in the BEA data are not as pronounced as might be expected based on the tenor of much of the public discussion.

The tax motivations for MNCs' use of havens are obvious, and there are clearly large potential gains for MNCs from cross-border tax planning. Nonetheless, there is also considerable evidence of significant frictions that limit MNCs' use of havens. The factors limiting MNCs' haven usage can be classified as follows: nontax frictions (such as the legal and business environment in different jurisdictions, a consideration that has largely been neglected in prior discussions of MNCs and havens), tax law provisions limiting profit shifting (which are discussed in detail in 
Section 3 below), and the costs of tax planning. The available evidence suggests the relevance of each of these elements. For instance, while MNCs locate holding companies disproportionately in havens, such companies are nonetheless also often found in nonhavens (suggesting the importance of nontax considerations in their location). There is also extensive evidence that MNCs' profit shifting is responsive to anti-avoidance rules in the tax laws of various countries. Most strikingly, many MNCs (indeed, a majority in certain widely-used datasets) do not have any haven affiliates at all, suggesting that tax planning is far from frictionless. The evidence for these different types of frictions casts some doubt on the widespread notion that MNCs are readily able to avoid taxes via the use of havens, and raises important questions about how to conceptualize the tax and nontax motivations for MNCs' haven activity.

A standard conventional account of MNCs' use of tax havens involves havens eroding the tax base of nonhavens by facilitating MNCs' profit shifting. This account implies that MNCs' haven activities are detrimental to nonhaven countries' welfare, and depicts nonhaven countries even large and powerful ones such as the US - as hapless victims of havens. However, as discussed in Section 3 below, tax law mechanisms that enable nonhaven countries to neutralize the impact of MNCs' use of havens have long existed. These include controlled foreign corporation (CFC) rules - under which residence countries (where MNCs are headquartered) tax certain types of income earned by the haven affiliates of their resident MNCs - and thin capitalization rules (TCRs), which limit the deductibility of interest in certain circumstances. The use of these tax law provisions has grown markedly in recent decades. Of course, they could potentially be implemented even more extensively. However, the failure to do so is a (presumably deliberate) policy choice of nonhaven countries' governments, rather than an unwelcome imposition by havens. MNCs' use of tax havens thus appears to rely crucially on its facilitation by the laws of nonhaven countries.

There are potential alternative accounts in which nonhaven countries are less complicit. For instance, MNCs' use of havens may exploit unintended interactions between the tax laws of different countries, as argued by the OECD (2013). However, the discussion in Section 3 suggests that this is unlikely to be the primary explanation of MNCs' tax haven use. It is also possible that nonhavens' failure to fully neutralize MNCs' use of havens may represent a policymaking error or oversight, or be attributable to political dysfunction. This would require, however, that such errors 
are systematic rather than random, and that policymakers are failing to respond to what has become a highly salient public concern about MNCs' profit shifting.

After explaining the tax law provisions noted above, Section 3 seeks to reframe the fundamental intellectual and policy issues raised by havens. In particular, it argues that the most relevant question is not how nonhaven countries should combat havens, but rather why nonhavens facilitate MNCs' use of havens. ${ }^{1}$ Framing the question in this way suggests (at least) two possible answers. One is that nonhaven countries use the tax law tools at their disposal suboptimally due to a collective action problem. This is theoretically possible, but (as discussed in Section 3) there are reasons to doubt that this is a complete explanation. The main alternative possibility is that $\mathrm{MNCs}$ ' haven activity serves the interests of nonhaven countries, at least as those interests are construed by their political systems. There is a strand of the public finance literature that suggests that under certain political and informational constraints (that prevent countries from directly taxing mobile and immobile capital differentially), MNCs' tax haven use can increase the welfare of nonhavens. To paraphrase what Voltaire wrote in an entirely different context, in this view "if tax havens did not exist, it would be necessary [for nonhavens] to invent them." Section 3 evaluates these possibilities and other potential explanations. It concludes that, regardless of the mechanism, it seems clear that MNCs' haven activity serves the interests of nonhaven countries (either individually or collectively or both). Of course, this does not in itself settle the question of whether MNCs' haven activity promotes nonhaven countries' "true" welfare, or merely their interests as refracted through the prism of various political distortions.

Section 4 reviews empirical estimates of the magnitude of profit shifting by MNCs to havens. It highlights the discrepancy between microeconometric estimates using affiliate-level data (which tend to find smaller magnitudes) and "macro" studies using aggregate data (which tend to find larger magnitudes). It links these differences to the distinction commonly drawn in the theory of public finance between "tax avoidance" and "behavioral responses to taxation," suggesting that microeconometric estimates may better capture the former notion. This distinction rests on the significance of nontax frictions - tax avoidance involves minimal nontax frictions, although it entails tax planning costs, whereas behavioral responses create distortions to the nontax

\footnotetext{
${ }^{1}$ It should be emphasized that the situation is quite different for individual evasion via havens: enforcement tools such as cross-border information exchange have not been available until recently, and there is no sense in which nonhavens necessarily facilitate individual evasion via havens.
} 
dimensions of firms' activities. As noted above, some evidence indicates that nontax frictions (such as the legal and business expertise available in different jurisdictions) constrains MNCs' tax haven use. This evidence suggests that some of what has traditionally been viewed as profit shifting (i.e. as cross-border tax avoidance) might arguably be reconceptualized as a type of behavioral response to tax differences across countries that is limited by nontax legal and business considerations. In any event, the concept of "behavioral responses to taxation" appears sorely in need of updating for a contemporary world in which physical infrastructure is often less important than the legal and business environment. Section 5 summarizes the main arguments and concludes.

\section{2) MNCs' Tax Haven Activity}

\section{1) An Overview of the Basic Facts about MNC Activity in Tax Havens}

This section begins by describing some basic facts about MNC activity in tax havens, using the aggregate country-level data provided by the BEA on the foreign operations of US-based MNCs. ${ }^{2}$ The BEA dataset is based on surveys of US multinational firms and collects extensive information about their affiliates abroad. As there exist legal penalties for failing to complete these surveys, it is generally thought that this dataset is highly reliable (although there are important problems of interpretation of aspects of this data, especially as it relates to havens, as discussed below). It has become a standard data source for scholars studying the behavior of US-based MNCs. An extensive academic literature has developed using both this aggregate country-level data (e.g. Hines and Rice, 1994; Clausing, 2016) and the confidential affiliate-level microdata on which the aggregate data is based (e.g. Desai, Foley and Hines, 2006; Dharmapala, Foley and Forbes, 2011).

For 2016 (the most recent year for which the BEA data is available), ${ }^{3}$ the BEA reports relevant measures for 201 separate countries and territories. To determine which of these are havens, this paper uses the list of havens reported in Dharmapala and Hines (2009, Appendix A, p. 1067). Dharmapala and Hines (2009) begin with the list of jurisdictions in Hines and Rice (1994, Appendix 2, p. 178), which is based primarily on various lists of havens produced by the US Internal Revenue Service (IRS). They update this list and match it with countries and territories

\footnotetext{
${ }^{2}$ This data is available at: https://www.bea.gov/international/dilusdop

${ }^{3}$ The 2016 data was preliminary, and potentially subject to revision, at the time this analysis was conducted. However, as discussed below, its main features with respect to haven activity have generally been quite stable over time.
} 
for which sufficient economic and institutional data was available in 2004. ${ }^{4}$ This classification of havens has been widely used in the subsequent academic literature, and other existing classifications substantially overlap with this list.

Dharmapala and Hines (2009, p. 1058) define tax havens as "locations with very low tax rates and other tax attributes designed to appeal to foreign investors." There are about 40 havens in their classification, typically small countries and territories that show a marked pattern of geographical clustering. Indeed, MNCs' use of havens appears to be influenced by geographical proximity to a perhaps surprising degree ${ }^{5}$ this may possibly reflect specialization by law and accounting firms. There is also a deeper question of why havens are distinct geographical entities at all. A corporate tax haven is, in essence, a mechanism for imposing a low or zero tax rate on certain types of income earned by MNCs. In principle, nonhaven countries could create domestic tax law vehicles to achieve this aim. However, there may be advantages to the geographical separation of havens. One possibility is that small jurisdictions that are reliant on incorporation fees for raising government revenue, and that lack a political constituency for high tax rates (being small enough that there is no meaningful domestic corporate sector that the public wishes to tax) may be more credible in setting low tax rates. ${ }^{6}$

Of the 201 countries and territories for which the BEA reports data for 2016, 35 are havens using the definition described above. Table 1 reports the values of various measures of US MNC activity available in the BEA data for these 35 countries and territories, the corresponding values for all foreign affiliates, and the former as a percentage of the latter. ${ }^{7}$ The data pertain to majority-

\footnotetext{
${ }^{4}$ This paper's data analysis involves further updating the list of havens with modifications to reflect subsequent (post2004) changes in the political status of some jurisdictions. For instance, the Netherlands Antilles was dissolved in 2010. The jurisdictions that were formerly part of the erstwhile Netherlands Antilles (Curaçao, Sint Maarten, and what the BEA terms "Netherlands Islands, Caribbean") are classified here as havens (which is how the Netherlands Antilles was classified in Dharmapala and Hines (2009)). In addition, there are some geographical units used by the BEA that do not correspond directly to jurisdictions in the Dharmapala and Hines (2009) classification. The most important of these is what the BEA terms "United Kingdom Islands, Caribbean." This is classified here as a haven, as it includes the Cayman Islands (in the view of many observers, perhaps the archetypal tax haven).

${ }^{5}$ For instance, Caribbean havens appear to be particularly important for US MNCs, while European and Mediterranean havens are important for European MNCs (although a partial exception is the prominence of Caribbean havens in FDI into China).

${ }^{6}$ However, the recent rise of patent box regimes - which impose low tax rates on income derived from patents - in many putatively nonhaven countries may indicate that this geographical separation is partially eroding.

${ }^{7}$ This comparison of foreign havens and foreign nonhavens follows naturally from the way that the aggregate BEA data is presented. To the extent that the income reported in foreign havens has been shifted from the US parent, then foreign havens share of foreign income may not fully capture the impact of profit shifting on the US parent and on US revenues. Note, however, that (as explained below) the aim here is not to use these shares as measures of the magnitude of profit shifting, but rather to highlight the pitfalls of doing so.
} 
owned foreign affiliates (MOFAs) of US parent firms in 2016. Figure 1 represents the same information in graphical form. The number of affiliates is included in Table 1 because it is sometimes referred to in public discussions of havens. However, it is not particularly meaningful as a measure of MNC operations, as a given amount of economic activity in a country can be divided among an arbitrarily large or small number of legal entities. ${ }^{8}$

Indicators of "real" economic activity in havens - the number of employees, employee compensation, tangible assets in the form of plant, property and equipment (PPE), R\&D and capital expenditures - suggest that approximately $5 \%$ to $15 \%$ of the foreign activity of US MNCs is in havens. However, nearly half of a measure that the BEA terms the "Net Income" of the foreign affiliates of US MNCs is reported in havens. ${ }^{9}$ This naturally prompts the question of what is measured by "Net Income." To clarify this, it is helpful to begin with the BEA measure known as "Total Income" (which is rather more akin to gross receipts than to income). Total Income is the sum of sales revenue, capital gains or losses, certain other receipts, and a category known as "income from equity investments." This last element is a purely notional adjustment reflecting the affiliate's pro rata share of income earned by other foreign affiliates in which it holds equity (Blouin and Robinson, 2019). Importantly, "income from equity investments" does not represent any dividend payments received by the affiliate from the lower-level affiliates that it owns, nor any realized capital gains from its ownership stake. Net Income is obtained by subtracting from Total Income the cost of goods sold (COGS), selling, general, and administrative (SGA) expenses, certain other costs, and foreign tax payments. To be clear, Net Income includes "income from equity investments" (the purely notional adjustment described above), and is also an after-tax concept as foreign tax payments are excluded. ${ }^{10}$

\footnotetext{
${ }^{8}$ Where the number of affiliates is particularly large, this is sometimes a legacy of mergers among MNCs (where the legal entities owned by each merging firm continue to survive).

${ }^{9}$ The patterns revealed by Table 1 are quite well-established and have been generally similar for some time. For example, Dharmapala (2014a, Table 2, p. 442) reports a similar set of calculations for 2011. These show that MOFAs of US-based MNCs earned $42.6 \%$ of the Net Income of all foreign affiliates of US-based MNCs in 2011. Thus, Table 1 and Figure 1 reflect a fairly stable pattern, although as discussed in the text the interpretation of these patterns is by no means self-evident.

${ }^{10}$ In principle, it is possible to construct a pretax version of Net Income by adding back foreign tax payments. However, this can only be done for a more limited set of jurisdictions - those for which foreign tax payments are reported - than that used in Table 1 and Figure 1 (there are 58 countries, of which 9 are havens, for which the foreign tax payment data is available for 2016). Haven affiliates' share of the pretax version of Net Income (i.e. of Net Income plus foreign tax payments) is about $48 \%$, and so is very similar to haven affiliates' share of Net Income in Table 1 and Figure 1.
} 
To illustrate the important role of "income from equity investments" in determining haven affiliates' share of Net Income, suppose (as illustrated in Figure 2) that a US parent firm owns $100 \%$ of a holding company in a haven $(\mathrm{H})$ and that this holding company in turn owns $100 \%$ of an affiliate in a foreign nonhaven country (F) with a $25 \%$ tax rate. Holding companies are MNC affiliates that hold shares of other affiliates in the same MNC group, and enable the MNC parent to control the latter affiliates indirectly - via a chain of ownership - rather than directly. Consider a scenario where the affiliate in $\mathrm{F}$ earns $\$ 100$, pays $\$ 25$ tax to the government of $\mathrm{F}$, and retains the remaining $\$ 75$. The holding company in $\mathrm{H}$ would then be recorded in the BEA data as having "income from equity investments" of $\$ 75$ (Blouin and Robinson, 2019). Suppose that the H affiliate generates no profits and pays zero taxes. Nonetheless, because of its ownership of the F affiliate, it would be recorded in the BEA data as having Net Income of \$75 (and the F affiliate would also be recorded as having Net Income of \$75).

There is a very reasonable justification for the BEA's accounting method, in that it provides a clear picture of the economic position of each affiliate on a jurisdiction-by-jurisdiction basis (including its holdings of interests in other affiliates). However, when used without fully taking account of the definition of "income from equity investments," the BEA data may potentially exaggerate the fraction of income that is generated in jurisdictions that host holding companies (whether or not these jurisdictions are havens, though it is likely to disproportionately affect haven affiliates). For the hypothetical US MNC in Figure 2, no foreign profit is actually generated or reported in the haven; however, the BEA's approach entails that 50\% of the MNCs' worldwide foreign "Net Income" is in the haven affiliate. Moreover, all of the Net Income attributed to the haven affiliate has in fact been subject to tax in country $\mathrm{F}$ at a quite high tax rate. ${ }^{11}$ The problem is potentially greatly magnified when an MNC uses chains of ownership that operate via holding companies in multiple havens (with the same $\$ 75$ of Net Income being attributed to several different haven affiliates). ${ }^{12}$

\footnotetext{
${ }^{11}$ The point that the income reported in havens has often been taxed by a higher-tax jurisdiction holds even absent the inclusion of "income from equity investments" in the BEA's income concept. For instance, if the $\$ 75$ of after-tax earnings of the $\mathrm{F}$ affiliate was not retained but rather repatriated to the haven holding company, then the latter would have $\$ 75$ of (true rather than phantom) income. However, this would still represent income that has been subject to a $25 \%$ tax elsewhere.

${ }^{12}$ This double counting (or multiple counting) problem can arguably be addressed using other BEA data series, such as the direct investment earnings series used by Clausing (2016). Blouin and Robinson (2019) propose using Net Income but subtracting "income from equity investments" to obtain a more meaningful income measure for affiliates.
} 
While the BEA data is not misleading in itself, it is clearly susceptible to serious misunderstanding. It is quite common in public discourse to point to descriptive statistics about Net Income to indicate the magnitude of profit shifting. ${ }^{13}$ However, the location of relatively large numbers of holding companies in havens is likely to lead to an upward bias in the fraction of Net Income observed in havens due to the inclusion of "income from equity investments." It has long been thought that the apparently high fraction of income in havens may in part be a mechanical artifact of how the use by MNCs of holding companies located in havens is reflected in the BEA data (e.g. Dharmapala, 2014a, p. 444). Recent work by Blouin and Robinson (2019) has clarified the central role of "income from equity investments" in producing this upward bias, and suggests that the associated double counting problem may be far more pervasive and important than was previously recognized. There is thus arguably rather less to the approximately $50 \%$ share of Net Income in havens in Table 1 and Figure 1 than meets the eye.

While profit shifting may seem to some observers to be an obvious explanation for the patterns in Table 1 and Figure 1, this potential bias suggests extreme caution in interpreting these patterns as being indicative of profit shifting. This applies in particular to the fraction of Net Income reported in havens, and to items such as royalties and interest that may pass through multiple haven affiliates in a chain of ownership (especially when they are reported in gross rather than net terms). The rather idiosyncratic definition and after-tax nature of the BEA concept of Net Income imply that it does not correspond to taxable income as defined by the tax laws of various jurisdictions. Hines (2010) argues that the share of "value added" (which equals sales minus the cost of inputs purchased, and excludes financial payments such as interest income or expense) may correspond more closely to taxable income, and provides a more meaningful measure of the role of havens, than does the share of Net Income (it is noteworthy that in Table 1, the share of value added in havens (17.7\%) is substantially smaller than the corresponding share of Net Income). Notwithstanding the potential mechanical upward bias in the BEA data, the differences between haven and nonhaven affiliates are rather less pronounced than might be expected, as the discussion of Tables 2-4 and Figures 3-7 below suggests.

Commonly accepted accounts of MNCs' haven use stress the following functions of havens (as discussed for instance in Dharmapala (2008)). First, it is thought to be common to locate holding companies in havens (as noted above). Second, haven affiliates are thought to be used in

\footnotetext{
${ }^{13}$ See Dharmapala (2014a) for a description and critique of this practice.
} 
financing the activities of other (nonhaven) affiliates. Debt finance provided by haven affiliates has clear tax advantages. For instance, when a haven affiliate receives equity injection from parent and lends to a high-tax affiliate, this generates interest deductions (subject to certain limitations) in the high-tax country and shifts income to the haven. Third, as has been widely discussed, MNCs may locate patents or other intellectual property in havens, with high-tax affiliates paying royalties to haven affiliates for the use of these assets.

The aggregate data on US MNCs' haven activities tends to be consistent with each of these channels. To illustrate this, it is helpful to use the more extensive data provided in the BEA's benchmark surveys. These are conducted every five years and provide a greater level of detail about the specific sources of affiliates' income (such as the categories highlighted in Table 2 and Figure 3 below). The most recent benchmark survey was conducted in 2014. However, the number of jurisdictions for which this more extensive data is provided is substantially smaller than for the 2016 data used in Table 1. In particular, Table 2 is based on data for 58 countries and territories, of which 9 are havens under the definition described above.

Table 2 shows the shares of haven affiliates (relative to all foreign affiliates) for selected categories of income from the 2014 benchmark survey. Figure 3 depicts the same information in graphical form. First, note that "income from equity investments" is disproportionately (though by no means exclusively) concentrated in havens: about half of "income from equity investments" is reported in haven affiliates. This indicates that holding companies are disproportionately located in havens, and that the double counting problem described above is likely to bias upwards the fraction of Net Income attributed to haven affiliates. Table 2 and Figure 3 also show that $37 \%$ of dividends are received by haven affiliates (from other affiliates lying below them in the chain of ownership). Capital gains and losses similarly reflect equity ownership of other affiliates (and may also reflect portfolio investment in passive assets). ${ }^{14}$ These measures are disproportionately large for haven affiliates relative to the 5\%-15\% benchmark for "real' activity, and support the inference that holding companies are disproportionately located in havens. At the same time, a substantial fraction of "income from equity investments" and dividends are in nonhaven affiliates; this is an

\footnotetext{
${ }^{14}$ Haven affiliates' share of capital gains slightly exceeds $100 \%$ because nonhaven foreign affiliates of US MNCs collectively made a (relatively small) capital loss in 2014, while haven affiliates collectively experienced a capital gain - thus, the latter's capital gain slightly exceeds the worldwide foreign capital gain of US MNCs in 2014.
} 
important piece of evidence regarding the role of nontax motivations and frictions in the location of holding companies (as discussed in Sections 2.2 and 4.2 below).

Royalties and license fees indicate the holding of intellectual property. These types of receipts are also disproportionately received by haven affiliates. About two thirds of the royalty and license fee receipts of the foreign affiliates of US MNCs in 2014 was earned by haven affiliates It is noteworthy that this is driven almost entirely by royalties and license fees paid by foreign nonhaven affiliates to haven affiliates, and not by royalty payments from the US parent to haven affiliates (about 90\% of haven affiliates' royalty and license fee receipts are from non-US entities). US tax law treats royalty income received by a foreign affiliate as US-source income (subject to full and immediate US taxation) if it is paid for property "located in the United States or ... for the use of or for the privilege of using in the United States patents, copyrights, secret processes and formulas, good will, trade-marks, trade brands, franchises, and other like property." 15 Royalty payments from the US parent to haven affiliates are thus heavily taxed, and the disproportionate share of royalties received by haven affiliates (to the extent that it reflects profit shifting) reflects profit shifting among foreign countries rather than from the US parent to haven affiliates.

Finally, interest receipts and the fraction of Net Income from the finance and insurance sectors point to havens' role as financial centers. About $29 \%$ of interest receipts by foreign affiliates are received by haven affiliates. While this is substantial, it is lower than the percentage of total assets in haven affiliates (reported in Table 1 and Figure 1). About half of the worldwide foreign Net Income of US MNCs from finance and insurance activities is received by haven affiliates.

Table 3 and Figure 4 report the corresponding measures using data from the prior benchmark survey in 2009. This shows an essentially similar set of patterns to that in Table 2 and Figure 3. The main differences relate to "income from equity investments" and capital gains. Haven affiliates' share of "income from equity investments" was substantially smaller in 2009 (although the fraction of dividends was similar to that in 2014). This may reflect growing complexity in the ownership structure of US MNCs, and hence an increase in the double counting of Net Income. Possibly due to the economic environment at the time, both haven and nonhaven

\footnotetext{
1526 U.S.C. $\S 861$.
} 
affiliates experienced capital losses. ${ }^{16}$ Interest receipts and the share of net income from finance and insurance activities were modestly smaller in 2009 than in 2014, but were not dramatically different. Overall, Table 3 and Figure 4 suggest that the patterns discussed earlier are fairly stable over time.

An alternative approach to understanding the same data is to compare the composition of the income of haven and nonhaven affiliates, particularly with respect to the categories of income that are highlighted in Tables 2 and 3. Table 4 uses data from the BEA's benchmark surveys in 2014 and 2009 to compute the fraction of Total Income (the BEA concept defined above, roughly corresponding to receipts plus "income from equity investments") derived from "income from equity investments," capital gains or losses, interest receipts, and royalties for haven and nonhaven affiliates (sales constitute the bulk of remainder of Total Income) ${ }^{17}$ Figure 5 represents this composition for 2014, while Figure 6 does so for 2009. The notional adjustment for "income from equity investments" constitutes a substantially larger share of Total Income for haven affiliates than for nonhaven affiliates (indicating the disproportionate location of holding companies in havens). The same is true of capital gains and losses (though the amounts involved are quite small in relation to Total Income). Royalties and license fees and interest receipts are also substantially higher for haven affiliates relative to nonhaven affiliates. However, the differences across haven and nonhaven affiliates are quite modest. Comparing 2014 and 2009, these patterns are generally similar over time (though, as in Tables 2 and 3, "income from equity investments" is larger for haven affiliates in 2014 than in 2009).

The overall picture that emerges from Table 4 is that sales constitute the primary source of gross receipts for both haven and nonhaven affiliates. This is somewhat less true for haven affiliates, but - notwithstanding the potential double counting problem noted earlier - the differences between haven and nonhaven affiliates are rather less pronounced than might be expected if taxes were the only consideration driving MNCs' use of havens. This is reinforced by Figure 7, which shows the fraction of Net Income derived from finance and insurance activities for haven and nonhaven affiliates in 2014: the former share is $15.69 \%$ while the latter is $12.24 \%$. While financial activities appear to be more important for haven affiliates than for nonhaven

\footnotetext{
${ }^{16}$ However, the capital losses of haven affiliates were disproportionately small (i.e. their capital gains were more positive than those of nonhaven affiliates, just as in 2014). In particular, $1.25 \%$ of all foreign capital losses were reported by haven affiliates.

${ }^{17}$ There is insufficient information in the aggregate data to undertake these calculations for Net Income.
} 
affiliates, the difference is fairly modest in magnitude. This overall picture also suggests that in a world without havens - for instance, if a multilateral agreement were to require and enforce a relatively high minimum tax rate for all countries - MNC activity may be somewhat different in terms of the location of holding companies, intellectual property and financing activities, but not to the extent that some might expect.

\section{2) Tax Avoidance and Other Motivations for MNCs' Tax Haven Activity}

It may seem strange to ask how much of MNCs' activity in havens is tax-motivated; this is, after all, tax haven activity. However, the answer is by no means obvious. To explain why, it is helpful to pose another counter-intuitive question, namely: why is all MNC income not reported in havens? This is very different from the implicit premise of much of the public discourse that asks why any significant amount of income is reported in havens. However, it is arguably the more relevant question, given MNCs' presumed objective of maximizing (after-tax) value and the potentially large gains from cross-border tax planning. The answers can be classified into three categories. The first is that there may exist nontax business reasons ("nontax frictions") for limiting profit shifting to havens. The second is that profit shifting may be limited by anti-avoidance rules in the tax laws of nonhaven countries, while the third is that tax planning itself may be costly or subject to various frictions.

Profit shifting involves the relocation of reported profits from higher-tax to lower-tax jurisdictions. A classic and fairly simple example, alluded to above, is a scenario in which a haven affiliate receives an equity injection from the MNC parent and lends to a high-tax affiliate. This generates interest deductions (subject to certain limitations) in the high-tax country and straightforwardly shifts income from the high-tax country to the haven (or, using slightly different terminology, it erodes the tax base of the high-tax country through what is known as "earnings stripping" or "interest stripping"; note, however, that interest deductions are available to both domestic firms and MNCs).${ }^{18}$ Moreover, these financing choices generate tax advantages without

\footnotetext{
${ }^{18}$ There are some conceptual difficulties in defining precisely what constitutes tax avoidance in the use of interest deductions, as interest deductibility is a (deliberately chosen) feature of tax law that is presumably intended to be used by firms. Desai and Dharmapala (2015) discuss these conceptual issues, and describe how the distinctively crossborder elements of tax avoidance via interest deductions can be addressed without affecting the use of interest deductions by domestic firms.
} 
having any substantive impact on the "real" business operations of the MNC (apart from any resources used in the process of tax planning). ${ }^{19}$

The absence of "real" effects implies that profit shifting can be viewed as a particular form of tax avoidance that is relevant for the cross-border activities of MNCs. Tax avoidance is commonly defined as "the lawful reduction of tax obligations, while maintaining the same substantive economic outcome" (Dharmapala, 2017, p. xv). The absence of distortions to decisions concerning real economic activity distinguishes profit shifting (and tax avoidance more generally) from real (or behavioral) responses to taxes. The latter is exemplified, for instance, by an MNC's decision to locate more tangible assets (e.g. build more factories) in a lower-tax location relative to an otherwise identical higher-tax location. This decision (while it may be privately optimal for the MNC in after-tax terms) reduces social welfare by placing some of these assets in the wrong location (from a pretax perspective). The impact of taxes on such real decisions is constrained by nontax frictions - for instance, the physical infrastructure in the lower-tax location may be less suitable. In contrast, pure forms of tax avoidance (including profit shifting) are constrained instead by tax law and by the costs of tax planning (as by assumption there are no real distortions apart from those associated with tax planning costs).

The patterns in the data described above suggest that tax havens are used by MNCs as locations for holding companies and intangible assets, and for the internal financing of affiliates. Is the tendency to locate holding companies in havens a form of profit shifting (i.e. does it have essentially no substantive economic effects)? This implicates the question of what factors determine the optimal location of holding companies. While tax considerations are clearly important ${ }^{20}$ there is evidence suggesting that both tax and nontax factors are relevant. The latter may include, for instance, the availability of local legal and business expertise relevant to

\footnotetext{
${ }^{19}$ It is worth noting that the welfare effects of profit shifting are more complex than may appear at first sight. Consider again the archetypal example above of interest stripping. Suppose that a US-based MNC injects $\$ 100$ of equity into its Bahamas affiliate, which then lends the $\$ 100$ to the same MNC's German affiliate at an interest rate of 5\%. The Bahamas affiliate will then receive $\$ 5$ of annual interest income. If the counterfactual (absent profit shifting) is that the US affiliate would have directly injected $\$ 100$ of equity into the German affiliate (and assuming that the dividends paid by the German affiliate to the US parent are not deductible in Germany, whereas the interest payments to the Bahamas affiliate are deductible), then profits have been shifted from Germany to the Bahamas (the counterfactual is not necessarily obvious, however: for instance, if the US parent would counterfactually have lent $\$ 100$ directly to the German affiliate and the interest payments are deductible in Germany regardless of whether they are paid to the US parent or the Bahamas affiliate, then the strategy described above could be viewed as shifting profits from the US to the Bahamas).

${ }^{20}$ For instance, for US MNCs, holding companies helped avoid repatriation taxes under the worldwide tax system that prevailed until 2017.
} 
managing the equity holdings of the affiliate. Desai, Foley and Hines (2006) analyze the affiliatelevel BEA data on US MNCs. They find that $12 \%$ of US MNCs' haven affiliates are holding companies, while $6 \%$ of nonhaven affiliates are holding companies. In their dataset, about $24 \%$ of holding companies are in havens. This share is disproportionate to the measures of real activity described above, indicating that holding companies are more commonly located in havens. However, this is clearly not true to the extent that would be expected in a scenario in which holding companies' location reflects only tax considerations.

Even absent the detailed affiliate-level ownership data used by Desai, Foley and Hines (2006), it is possible to draw some inferences about the distribution of holding companies across havens and nonhavens using the aggregate BEA data on "income from equity investments" in foreign affiliates. As discussed above, this measure reflects an affiliate's ownership of other affiliates, and so provides a strong indication of the presence of holding companies. Table 2 and Figure 3 show that just under $50 \%$ of income from equity investments was attributed to haven affiliates in 2014. While this is clearly disproportionate, it indicates a substantial presence of holding companies in nonhavens. However, there may well be favorable tax attributes of nonhaven jurisdictions that influence holding company location. In general, the favorable tax attributes of nonhavens (such as territorial tax regimes and zero withholding taxes on royalties, interest and dividends) tend to be matched or outdone by havens. However, the Netherlands is arguably a special case, in that it has a well-established special tax regime for foreign holding companies; it may also be preferred by MNCs to havens with similar regimes (for instance, because the Netherlands has a more extensive tax treaty network than many havens). Indeed, about 18\% of "income from equity investments" was earned by Dutch affiliates of US MNCs in 2014. While this is also disproportionate to measures of real activity, it nonetheless leaves a significant fraction - nearly one third - of "income from equity investments" in nonhavens other than the Netherlands (for instance, about $7 \%$ is in the UK and $6 \%$ in Canada). ${ }^{21}$

The evidence on holding companies is particularly significant in suggesting not merely that there are limits to tax planning, but specifically that they include substantial nontax frictions. If it were true that holding company structures are entirely tax-motivated, then anti-avoidance rules in

\footnotetext{
${ }^{21}$ In the 2014 BEA data, aggregate worldwide income from equity investments of US MNCs' majority-owned foreign affiliates was $\$ 718.79$ billion. Of this amount, $\$ 356.23$ billion was in haven affiliates (using this paper's classification of haven jurisdictions), $\$ 128.45$ billion in Dutch affiliates, $\$ 52.49$ billion in UK affiliates, and $\$ 44.84$ billion in Canadian affiliates.
} 
nonhaven countries' tax laws and tax planning frictions would reduce the prevalence of holding company structures. However, under the assumption of a pure tax motivation, these factors alone would not cause holding companies to sprout in nonhaven jurisdictions. Yet, a substantial fraction of holding companies are located in nonhavens. This implies that there are significant nontax considerations that determine the location of holding companies: not all holding companies are in havens because these nontax business considerations presumably outweigh tax advantages in some (but not all) cases.

Nontax factors (which may include the jurisdiction's legal infrastructure and the availability of business expertise in managing royalty payments from other affiliates) are also likely to play a role in the location of intellectual property (IP). In general, the empirical evidence suggests that IP location is very sensitive to taxes. For instance, Dischinger and Riedel (2011) use the balance sheet item "intangible fixed assets" from the Amadeus database of European affiliates to test whether intangible asset holdings are disproportionately concentrated among affiliates in low-tax jurisdictions, controlling for unobserved affiliate effects that may influence the ownership of intangibles. They find a semi-elasticity of 1.7 - i.e. a 10 percentage point lower tax rate in an affiliate relative to the average for the MNC group leads to a $17 \%$ higher holding of intangible assets. $^{22}$ This is a substantial and noteworthy tax effect, but does not seem to indicate that IP location is solely determined by tax considerations. However, the evidence is less clear than for holding companies in terms of ruling out anti-avoidance rules and tax planning frictions as explanations for why not all IP is located in havens. Anti-avoidance rules and tax planning costs (as well as nontax frictions) may potentially explain why higher-tax affiliates hold or retain IP (which, after all, must be held by one affiliate or another).

With respect to the role of havens as financing centers, the pure tax motivation underlying the interest stripping example above is very clear. However, it should be noted that many tax havens are also (perhaps not entirely coincidentally) offshore financial centers (OFCs). They are thus the home of extensive financial expertise and infrastructure, which may reinforce the tax motivation to locate financial activities in havens. ${ }^{23}$ Tax and nontax motivations are difficult to

\footnotetext{
${ }^{22}$ To illustrate, suppose that an MNC group faces an average tax rate of $20 \%$ and that a typical affiliate of this MNC facing this tax rate holds $\$ 100$ worth of IP. Then, an affiliate in a zero-tax haven would hold $\$ 134$ worth of IP.

${ }^{23}$ Rose and Spiegel (2007) find evidence suggesting that the presence of OFCs may have some positive effects on nearby countries, for instance, because competition from OFCs potentially spurs financial development in neighboring countries.
} 
disentangle in this context, and the nontax financial advantages of havens may originally have arisen from agglomeration effects attributable to their tax advantages. However, Figure 7 suggests that financial activities are in aggregate not that much more important to haven affiliates than to nonhaven affiliates, and Table 2 indicates that a substantial fraction of financial activities are carried out by nonhaven affiliates.

The wider implications of these facts and the conceptual framework described above for how profit shifting should be understood and measured are taken up further in Section 4 below, following a review of the literature on the magnitude of profit shifting. For now, it is sufficient to bear in mind that the data indicates that there appear to be important frictions associated with MNCs' use of havens for tax avoidance. A particularly striking piece of evidence along these lines in the academic literature is that a substantial fraction of MNCs have no haven affiliates. Desai, Foley and Hines (2006), using the affiliate-level BEA data, find that in 1999 only 59\% of U.S. firms with significant foreign operations had affiliates in tax haven countries. Dharmapala and Riedel (2013), using an Amadeus sample of European MNC affiliates over 1995-2005, report that only $58 \%$ of these affiliates belong to MNCs that include at least one affiliate in a non-European tax haven. More recent evidence on this point comes from the German MNCs analyzed in Gumpert, Hines and Schnitzer (2016), using the Microdatabase Direct investment (MiDi) dataset provided by the German Bundesbank. Among these MNCs, only about $20 \%$ have any tax haven affiliates. The ownership of haven affiliates appears responsive to tax motivations: among German manufacturing MNCs, higher foreign tax rates are associated with a higher likelihood of having tax haven affiliates. However, on average, surprisingly few German MNCs use tax havens.

Why do more MNCs not use haven affiliates? The direct costs of establishing a haven affiliate - typically, incorporation fees paid to the haven government - are relatively modest, yet many MNCs manifestly do not find this cost worthwhile. One possibility consistent with this observation is that there exists a substantial fixed cost of tax planning (i.e. of obtaining legal and accounting services and structuring the legal form of affiliates), so that many MNCs - especially those that are smaller - do not undertake any tax planning. Another possibility is that governments' anti-avoidance rules constraining profit shifting - such as those described in Section 3 below - may be sufficiently effective that many MNCs do not expect to derive tax benefits from establishing haven affiliates.

\section{3) Tax Havens and Secrecy}


In popular discussions of tax havens, great emphasis is placed on the importance of secrecy in haven jurisdictions (achieved, for instance, through laws relating to the confidentiality of financial accounts). Havens are indeed sometimes described as "secrecy jurisdictions." However, secrecy plays at most a minor role in MNC haven activity. As the extensive data discussed in Section 2.1 suggests, the activities of MNCs in havens - including those involving tax avoidance - take place in the bright sunshine of academic, financial and media scrutiny. On the other hand, secrecy has historically been important to tax evasion by individuals through the holding of financial accounts in tax havens.

Tax evasion (which is not to be confused with tax avoidance) is the "nonpayment of legally owed taxes, where it is assumed that the law clearly specifies the obligations of the taxpayer." (Dharmapala, 2017, p. xv). Individuals are typically subject to personal income tax in their country of tax residence. The tax laws of most countries that implement personal income taxation require that income generated in foreign financial accounts is reported and taxed by the residence country. Individuals who hold foreign financial accounts and fail to report the income these accounts generate to their home government are thus engaged in tax evasion. The confidentiality laws of some tax havens facilitated such evasion by reducing the likelihood of detection by the home government (although until recently there was quite limited enforcement even for foreign financial accounts held in nonhavens).

As will be clear from this description, MNC activities in havens have essentially nothing in common with evasion by individuals. It is thus important to distinguish between MNCs' and individuals' use of havens (e.g. Dharmapala, 2008). MNCs' activities in havens are generally lawful (although tax planning may involve taking more or less aggressive positions in the face of legal uncertainty). In contrast, individual evasion is typically unlawful and relies in part on secrecy. Moreover, the spread of information exchange among governments about individuals' foreign financial accounts (especially the introduction of the automatic exchange of information among governments) is arguably making individual evasion via tax haven financial accounts (and foreign accounts more generally) largely a phenomenon of the past. In 2010, Congress enacted the Foreign Account Tax Compliance Act (FATCA), which essentially compels non-US financial institutions to report to the US accounts held by US individuals (e.g. Dharmapala, 2016). This represents a 
unilateral approach by the US, while the OECD and G-20 have developed a multilateral approach to information exchange known as the Common Reporting Standard (CRS). ${ }^{24}$

There are some reasonable questions that remain about whether the social welfare gains from reducing tax evasion - which depend on the incremental social value of the revenue collected when it is in government rather than private hands - exceed the compliance costs for financial institutions of reporting to a wide variety of foreign governments (e.g. Dharmapala, 2016). Despite this caveat, the disappearance of individual evasion through offshore financial accounts is obviously a welcome development in terms of tax compliance, revenue generation, and the integrity of the world's personal income tax systems. There is some historical irony, though, in that this development has occurred in an era of what Ginsburg and Huq (2018) term "democratic retrogression" - a well-documented phenomenon in which democratic values and practices are in retreat globally in the face of the rise of elected strongmen with authoritarian inclinations. Secrecy jurisdictions are thus disappearing at the same time that there may arguably be a greater need for those who reasonably fear persecution by such regimes to protect their assets (however, Ginsburg and Huq (2018) also find that outright dictatorships have become less common in recent years, which may potentially reduce the need for secrecy jurisdictions).

While it has conventionally been thought that secrecy plays little or no role in MNCs' haven activity (e.g. Dharmapala, 2008), there is an emerging body of evidence that adds some nuance to this picture. For instance, Braun and Weichenrieder (2015) analyze the impact on the foreign operations of German-based MNCs of the signing of Tax Information Exchange Agreements (TIEAs), which provide for enhanced exchange of information among governments. They find that the probability of a German MNC owning an affiliate in a haven falls after the signing of a TIEA between that haven and Germany. Bennedsen and Zeume (2017) analyze stock market reactions to the signing of TIEAs involving tax havens, using a dataset of 17,331 publicly listed firms in 52 countries. They find that the signing of a TIEA between a firm's residence country and a tax haven is associated with a $2.5 \%$ increase in firm value. They interpret this result as indicating that the insiders of firms with haven affiliates use these affiliates for activities involving the diversion of value from shareholders; these activities, they argue, are constrained by the greater transparency created by TIEAs.

\footnotetext{
${ }^{24}$ Casi, Spengel and Stage (2019) report evidence suggesting that the US is emerging as, in effect, a major secrecy jurisdiction for tax evasion by non-US individuals, as the US does not participate meaningfully in the CRS.
} 
O’Donovan, Wagner and Zeume (2019) link previously secret offshore entities revealed by the "Panama Papers" leak that occurred in 2015 to 338 publicly listed firms around the world. They find a negative market reaction of about $1 \%$ of firm value to the revelation of these entities. They interpret this result as indicating that activities undertaken through these secret entities (such as the bribery of foreign officials) are value-enhancing for shareholders; for instance, these firms reduce their subsequent activity in countries with higher levels of corruption. The negative reaction is less pronounced for firms with weaker corporate governance (suggesting that the secret activities of these firms were less likely to be value-enhancing for outside shareholders).

This new evidence suggests that havens' secrecy matters (or rather, mattered while it existed) to certain peripheral MNC activities, such as the bribery of government officials. It does not imply that major MNCs use havens to engage in tax evasion per se (as defined above), something for which the literature has produced no evidence and that seems unlikely on conceptual grounds. A framework that can unify much of this new evidence is provided by the agency perspective on corporate tax avoidance developed by Desai and Dharmapala (2006; 2008; 2009a, b; 2018) that highlights potential complementarities between tax avoidance (whether or not linked to havens) and managerial or insider opportunism. For instance, the complexity of transactions undertaken to avoid taxes may impede shareholder monitoring and thus reduce the cost of insider opportunism. Stronger corporate governance (increasing the alignment of interests between shareholders and insiders) then has a potentially ambiguous effect on tax avoidance activity. While stronger governance prompts insiders to increase firm value by engaging in tax avoidance, it may also dissuade insiders from engaging in acts of opportunism that are complementary with tax avoidance.

While this agency framework is alluded to in some of the literature on corporate tax havens and secrecy, its implications for the questions addressed in this paper have not been explicitly articulated. Arguably, it is possible to use the agency perspective on corporate tax avoidance to construct a theory of how havens may potentially reduce the welfare of nonhavens. In this view, the existence of havens enables firms to engage in tax avoidance (at least to a greater degree than otherwise). When firms engage in tax avoidance, insiders of some firms (namely, those with weaker governance) will tend to also divert more value from shareholders. Shareholders (who are overwhelmingly resident in nonhaven countries) will potentially be worse off if the amount diverted exceeds the increase in shareholder value from greater tax avoidance. 
However, a limitation of this claim is that the underlying problem is that corporate governance in nonhaven jurisdictions is not as uniformly strong as it could be, rather than that havens exist. If corporate governance were perfect, shareholders would be unambiguously better off with more tax avoidance opportunities (and therefore better off due to the existence of havens). Moreover, shareholders could in principle replicate firm behavior in a world without havens by forbidding or strongly disincentivizing the establishment of haven affiliates by managers. The Desai-Dharmapala theory presumes the imperfect observability of managerial actions (e.g. whether a particular strategy is primarily for tax avoidance or for diversion); however, it should be feasible for shareholders to impose and enforce a simple bright-line rule such as not establishing any haven affiliates.

Separately, it is also possible to argue that havens that provide a domicile for secret entities make the (typically, developing) countries whose officials are bribed worse off by exacerbating problems of corruption (if there would counterfactually be less bribery absent havens). Again, however, the fundamental problem is corruption in these countries rather than the existence of havens. Moreover, the welfare implications of increased corruption in a second-best setting are by no means obvious.

\section{3) Tax Havens and the Welfare of Nonhaven Countries}

This paper seeks to understand the consequences of corporate tax havens for the welfare of nonhaven countries. In approaching this issue, it is important to emphasize that existing elements of tax law already provide nonhaven countries with a powerful set of tools that can effectively neutralize the tax impact of havens. These include, among others, controlled foreign corporation (CFC) rules and thin capitalization rules (TCRs). Before proceeding, however, it is helpful to make more explicit the definitions of certain relevant international tax law concepts. In the terminology of international taxation, the country in which the MNC parent is domiciled (either incorporated or managed and controlled, depending on the country) is known as the "residence" country. A country in which MNC affiliates undertake business activity is known as a "source" country. Income generated by normal business operations in the source country is referred to as "active" income; income not associated with these business activities (such as interest and royalties) is referred to as "passive" income.

\section{1) CFC Rules}


Suppose that country A (in which an MNC known as Firm A is resident) has a corporate tax rate of $20 \%$. Firm A holds $100 \%$ ownership of affiliates in country B (a nonhaven that also imposes a $20 \%$ corporate tax) and in country $\mathrm{H}$ (a haven with a zero tax rate). In the parlance of international taxation, the affiliates in B and $\mathrm{H}$ are known as "Controlled Foreign Corporations" (CFCs). Most countries with significant outbound FDI impose what are known as CFC rules. These rules specify a minimum tax rate and provide that if a resident MNC earns passive income in any jurisdiction with a tax rate below this minimum, it pays tax to the residence country at the residence country's tax rate. For example, suppose that country A imposes a CFC rule that specifies a minimum tax rate on foreign passive income of $10 \%$. Then, any passive income earned by Firm A in country H (the zero-tax haven) will be subject to taxation by country A at its regular $20 \%$ tax rate. Thus, a CFC rule taxes passive income earned in tax havens at the residence country rate. Such a rule clearly eliminates the incentive for Firm A to shift profits from A to H. However, it also eliminates the incentive for Firm A to shift profits from B to H. This latter effect increases the foreign tax payments made by Firm A (to the government of country B). These increased foreign tax payments represent a reduction in the national welfare of country A.

A simple but useful characterization of national welfare in this context is to define it as the sum of the after-tax profits of a country's resident MNCs and the aggregate tax revenue collected by the country's government (e.g. Dharmapala, 2014b). This is obviously a simplification, as funds in the hands of the government may be more socially valuable than those in the hands of the MNC's shareholders. However, it suffices for the purposes of this discussion of international tax policy and the strategic interactions among countries. For instance, it captures the idea that resident MNCs (despite growing global financial integration) often remain predominantly owned by shareholders who are also resident in the same country (a phenomenon sometimes termed "equity home bias"). It also highlights the contrast between foreign-to-foreign shifting (which unambiguously increases the residence country's national welfare) and shifting from the residence country to havens (for instance, US-to-haven shifting by US MNCs reduces US tax revenue but this negative effect is entirely or partially offset by higher national welfare due to increased aftertax profits for US MNCs). The discussion below emphasizes foreign-to-foreign shifting because of its clearer national welfare implications, but this is not intended to deny the importance of shifting from the residence country to havens. It should also be stressed that this simple framework 
is not suitable for analyzing the domestic effects of tax policy, where distributional considerations within a country play a significant role.

Consider first the outcomes in the absence of a CFC rule (as illustrated in Figure 8), assuming that the costs of tax planning are $\$ 2$ per country from which profits are shifted. Suppose also that Firm A earns $\$ 50$ in country A, $\$ 50$ in country B and zero in the haven $\mathrm{H}$, before taxes and prior to any profit shifting. When country A does not impose a CFC rule, Firm A will find it worthwhile to shift all of its profits from both $A$ and $B$ to $H$ (thereby saving $\$ 10$ of tax in each of $A$ and $B$, and incurring a $\$ 2$ cost of tax planning in each country). Firm A's profits, taking account of the $\$ 4$ cost of profit shifting, will be $\$ 96$ and country A's revenue will be zero (so that the national welfare of country A is $\$ 96$ ).

Now consider the introduction of a CFC rule by country A (as illustrated in Figure 9). Firm A will no longer shift profits from either A or B to the haven. Doing so would result in the income reported in $\mathrm{H}$ being taxed at country A's $20 \%$ tax rate, while Firm A would also pointlessly incur a $\$ 4$ cost of tax planning. Thus, Firm A would instead pay $\$ 10$ of tax to each of governments A and $\mathrm{B}$, and be left with after-tax profits of $\$ 80$. The government of country A now raises $\$ 10$ of revenue, so country A's national welfare is $\$ 90$. Country A's national welfare falls upon the introduction of the CFC rule because of the increased tax payments by Firm A to country B. The higher revenue for foreign governments is not a loss from a global perspective, and so a CFC rule may be globally optimal (as in this example, though not necessarily in all circumstances). It generally increases the residence country's tax revenue. However, it may well reduce the national welfare of a country that introduces it, while generating positive revenue spillovers for other nonhaven countries (e.g. country B in the example gains $\$ 10$ of revenue). As discussed below, residence countries thus face a collective action problem in introducing CFC rules, and are likely to do so to a suboptimal extent (e.g. Dharmapala, 2014b; Haufler et al., 2018).

CFC rules were pioneered by the US, in the form of what are known as the Subpart F provisions enacted in 1962 . These rules made passive income earned in low-tax foreign jurisdictions subject to immediate taxation by the US (whereas otherwise the US taxation of foreign income was deferred until the repatriation of that income to the US parent). Since then, even as CFC rules have spread around the world, US CFC rules have undergone a significant transformation. In 1996, the US Treasury issued what are known as the "check-the-box" (CTB) regulations. These regulations enable firms to choose their organizational form for tax purposes 
(e.g. as a C-corporation or as a pass-through entity) by filing a simple form on which the appropriate box could be checked. The CTB (or "entity election") regime replaced a complex set of rules determining firms' tax status. However, it has also had the consequence of facilitating tax avoidance by US-based MNCs using what are known as "hybrid entities" (e.g. Altshuler and Grubert, 2005). Hybrid entities are classified in two distinct ways, for instance as separately incorporated affiliates under the tax rules of a foreign country and as unincorporated branches for US tax purposes.

Figure 10 illustrates the impact of the CTB regulations on the operation of the US CFC rule. Suppose a US-based MNC has affiliates in B and a haven H (with the same characteristics assumed above). The impact of the US CFC rule can be avoided by using the CTB regulations as follows. Firm A can elect (for US tax purposes) to have the haven affiliate treated as an unincorporated branch of the $\mathrm{B}$ affiliate. This makes the passive income received by the $\mathrm{H}$ affiliate invisible to the US tax system (the box outlined by dashed lines indicates the entity that is perceived by the US). At the same time, it is possible to treat the haven affiliate as a separately incorporated entity from the B affiliate under the tax laws of country B (thus enabling, for instance, interest or other payments from B to $\mathrm{H}$ to be deductible in country B). The CTB regulations thus facilitate the avoidance of country B's tax by US-based MNCs, notwithstanding the US CFC rule. ${ }^{25}$ In effect, it makes the US CFC rule elective, and can be viewed as way to avoid the increased foreign tax payments that imply negative consequences of CFC rules for national welfare. This situation, however, is unique to the US and does not apply to the CFC rules of other countries.

CFC rules provide residence countries with a very powerful means of eliminating profit shifting to havens by their resident MNCs. The empirical evidence suggests that CFC rules are highly effective. For instance, using a global dataset of MNCs, Markle and Robinson (2012) find that CFC rules imposed by the residence country reduce MNCs' use of tax havens. Using the MiDi dataset on German MNCs provided by the German Bundesbank, Ruf and Weichenrieder (2012) find that Germany's CFC rule is quite effective in limiting the amount of passive income located by German MNCs in low-tax countries.

\footnotetext{
${ }^{25}$ Desai and Dharmapala (2009a) use this reform as a source of exogenous variation in US firms' tax avoidance activities. Albertus (2018) offers evidence that the CTB regulations increased the after-tax return to innovation and increased innovative activity in the US by US-based MNCs.
} 
Clifford (2019) uses a global dataset of MNC affiliates over 2003-2013 from the Orbis database compiled by the Bureau van Dijk, and codes the CFC rules (if any) applicable to each MNC affiliate in each of these years (based on the residence country of the MNC affiliate's parent and the tax characteristics of the source country). She finds evidence that MNCs reallocate profits from affiliates just below the tax rate threshold at which the CFC rule applies to those just above this threshold. ${ }^{26}$ MNCs also tend to establish fewer affiliates in countries with tax rates below the CFC rule's threshold. Clifford (2019) also estimates that a residence country introducing a CFC rule obtains about half of the resulting increase in tax revenue, with the other half accruing to other nonhaven countries. The revenue spillovers of CFC rules illustrated by the simple example in Figure 9 are thus empirically quite relevant. ${ }^{27}$

\section{2) Thin Capitalization Rules (TCRs)}

While CFC rules are imposed by residence countries, TCRs are an instrument of primary relevance to source countries. TCRs limit the use of internal debt within MNCs to erode the tax base of nonhaven source countries. Such base erosion occurs most straightforwardly through the types of interest stripping transactions described in Section 2, in which a haven affiliate receives an equity injection from the MNC parent and lends to a high-tax affiliate. This generates interest deductions in the high-tax country and shifts income from the high-tax country to the haven. There are two main forms of TCRs (e.g. Büttner et al., 2012; Ruf and Schindler, 2015). The originally predominant type is based on safe harbor rules that set a maximum ratio of debt to total capital (the sum of debt and equity) and restrict the tax deductibility of interest payments (either for related-party interest or for all interest, depending on how a country's tax law specifies these restrictions) when this ratio is exceeded. ${ }^{28}$

\footnotetext{
${ }^{26}$ For instance, in the example above, MNCs based in country A would reallocate profits from countries with tax rates below $10 \%$ to those with tax rates above $10 \%$ as passive income reported in the former would incur country A's $20 \%$ tax.

${ }^{27}$ Prettl (2018) also uses Orbis data and finds evidence suggesting that CFC rules are associated with substantially lower reported financial income in haven affiliates. He also reports evidence of bunching at thresholds created by CFC rules.

${ }^{28}$ A typical safe harbor rule applying only to related-party debt operates as follows (in somewhat stylized form). Suppose that a German MNC parent injects $€ 100$ into its Portuguese affiliate. Assume that (as reported by Büttner et al. (2012, Table 1, p. 932) for 2005) Portugal has safe harbor ratio of 2:1, pertaining only to related-party debt. This implies that interest payments from the Portuguese affiliate to other affiliates of the same MNC are fully deductible when the amount of debt owed by the Portuguese affiliate to external and related-party lenders is no higher than $€ 200$. If its debt exceeds $€ 200$, then interest deductions for related-party debt are partially disallowed. Specifically, a fraction of related party interest corresponding to the ratio of excess debt (exceeding €200) to total debt is disallowed. It may seem that (if the choice of inter-affiliate debt is largely frictionless) the optimal strategy for an MNC would involve nonhaven affiliates locating precisely at the safe harbor threshold in order to maximize interest deductions. Büttner,
} 
More recently, many countries have adopted an alternative form of TCR, generally known as an earnings (or interest) stripping rule. ${ }^{29}$ This involves specifying a limit to interest deductions as a fraction of pretax income. That is, an affiliate's interest deductions (either for inter-affiliate debt or for all debt) are restricted to some maximum fraction of some specified notion of income, typically earnings before interest and taxes (EBIT) or earnings before interest, taxes, depreciation and amortization (EBITDA). Disallowed interest is typically carried forward and can potentially be used in a future year, but only in accordance with the TCR's limitations.

Consider a simple earnings stripping rule adopted by country B in the example above. Suppose in particular that country B restricts interest deductions to $30 \%$ of EBIT, as illustrated in Figure 11. Firm A (the MNC based in country A) injects $\$ 100$ of equity into its haven affiliate, which then lends this $\$ 100$ to Firm A's affiliate in country B. Suppose that the (arm's length) interest rate is $10 \%$. In the absence of a TCR, affiliate B would be able to deduct $\$ 10$ of interest in country B. With B's TCR (as specified above), affiliate B's interest deductions are constrained. Assume that EBIT for affiliate B is $\$ 12$; then, interest deductions are limited to $\$ 3.60$. Country B's TCR thus limits the profit shifted from B to $\mathrm{H}$ to $\$ 3.60$, rather than the $\$ 10$ that could be shifted absent the TCR.

TCRs are thus a powerful instrument by which source countries can limit the erosion of their tax base by MNCs and neutralize the impact of havens. Indeed, a sufficiently strict TCR can in principle eliminate interest stripping to havens. Büttner et al. (2012) use data on the foreign affiliates of German MNCs to show that the introduction and strengthening of TCRs reduces the use of inter-affiliate debt. However, while the adoption of TCRs by source countries prevents tax base erosion and generates tax revenue, it also increases effective tax rates on investment by MNCs (when taking account of the more limited possibilities for outbound profit shifting). There are thus potential disadvantages to introducing TCRs, most notably that inbound investment by MNCs may be discouraged to some degree by higher effective tax rates.

\section{3) The Global Strengthening of Rules against Profit Shifting to Havens}

Overesch and Wamser (2016), however, report evidence that the majority of affiliates locate below the threshold; in their data on foreign affiliates of German MNCs, about $25 \%$ of affiliate-year observations exceed the safe harbor threshold.

${ }^{29}$ Mardan (2017) and Gresik, Schindler and Schjelderup (2017) develop theoretical models of the choice between safe harbor rules and earnings stripping rules. The 2017 US tax legislation moved the US from a safe harbor debt-equity ratio (of 1.5 to 1) to an earnings stripping rule limiting interest deductions more broadly to $30 \%$ of income - see 26 U.S.C. $\S 163(\mathrm{j})$. 
The main implication of the discussion in the preceding subsections is that nonhaven countries have available tax law provisions that are extremely powerful in neutralizing the tax advantages associated with MNCs' use of havens. Moreover, these tools have been increasingly widely adopted by countries in recent years. Dharmapala (2019) constructs a dataset of CFC rules and TCRs for all OECD member countries in 2000 and $2014 .{ }^{30}$ This builds on the coding of these provisions by Haufler et al. (2018), but is modified in certain respects to enable quantification. In particular, CFC rules can be characterized in a straightforward manner as establishing a minimum tax rate on foreign passive income earned by a country's resident MNCs. This is given by the foreign tax rate threshold for the CFC rule to apply. For example, in the simple illustration in Section 3.1, country A imposes a CFC rule with a tax rate threshold of $10 \%$, implying that any foreign passive income earned by Firm A that is taxed at (strictly) less than 10\% becomes subject to taxation by country A at its tax rate of $20 \%$. This implies that Firm A's foreign passive income can never be taxed at a rate less than $10 \%$. If located in a haven with a tax rate below $10 \%$, it will be taxed at $20 \%$ by country A; otherwise, it is taxed at the local tax rate, which cannot be below $10 \%$ without triggering the $\mathrm{CFC}$ rule. Note that the absence of a CFC rule (which was fairly common among OECD countries in 2000) entails that the minimum tax rate on foreign passive income earned by a country's resident MNCs is zero: if passive income is earned in a zero-tax jurisdiction, then it faces a zero tax rate.

As shown in Figure 12, the median across OECD countries of this minimum tax rate on foreign passive income increased from zero to $12 \%$. The corresponding mean increased more modestly from $10.8 \%$ to $10.9 \%$ (as also shown in Figure 12). The strengthening of CFC rules among OECD countries is more marked if the minimum tax rate on foreign passive income is scaled by the country's corporate tax rate. Arguably, this scaling is sensible because many CFC rules specify the foreign tax rate threshold as a fraction of the country's corporate tax rate. Figure 13 shows that the mean across OECD countries of this ratio has increased from 0.34 to 0.42 . The median across OECD countries of this ratio has increased more markedly, from 0 to 0.5 . This

\footnotetext{
${ }^{30}$ There are 34 countries in the sample (consisting of all member countries of the OECD as of 2014). One of these countries is the US, for which it is difficult to characterize a CFC rule because of the CTB regulations described in Section 3.1. However, the findings are robust to either coding the US as having or not having a CFC rule (bearing in mind that the CTB regime applied in both 2000 and 2014 and so does not affect the difference in rates between those two years).
} 
implies that the median OECD country requires its resident MNCs to pay tax on their foreign passive income at a rate of at least half its regular corporate tax rate.

The particularly substantial increase in the median across OECD countries of the minimum tax rate on foreign passive income indicates that CFC rules have become substantially more widespread among OECD countries. This development is illustrated in Figure 14, which plots the minimum tax rate on foreign passive income (scaled by the corporate tax rate) for each country in the sample. There are a substantial number of countries with zero minimum rates (i.e. no CFC rules) in 2000 that introduced CFC rules (and hence have positive though relatively modest minimum tax rates on foreign passive income) by 2014. On the other hand, countries that already had CFC rules in 2000 have fairly similar ratios of minimum tax rates on foreign passive income to their corporate tax rates in 2014 (albeit in an environment in which the average corporate tax rate has fallen). The widening of the distribution of CFC rules, however, is particularly important in practical terms: even a CFC rule with a fairly low foreign tax threshold can completely deter profit shifting to zero-tax havens.

TCRs of the safe harbor variety establish a maximum ratio of debt to equity above which interest deductions are disallowed. In comparing TCRs across countries and over time, it is convenient to recharacterize this as a minimum ratio of equity to total capital (equity plus debt) above which interest deductions are allowed. The absence of a TCR implies that this minimum fraction of equity is zero (so that interest payments are deductible without restrictions). TCRs of the earnings stripping rule variety can be characterized straightforwardly by the fraction of pretax income that is specified as the maximum amount of deductible interest ( $30 \%$ of EBIT in the simple example above). Figure 15 shows that the mean fraction across OECD countries of equity in MNC affiliates required for interest deductibility has risen from 0.14 to 0.22 . This indicates that safe harbor rules have been strengthened, thereby reducing opportunities for profit shifting. For earnings stripping rules, the mean fraction across OECD countries of income that is subject to interest deductions has fallen from 1 to 0.65 . Thus, only about two thirds of MNC affiliates' income was potentially subject to interest deductions in 2014.

\section{4) Why are Rules against Profit Shifting not used (even) more Extensively?}

The conceptual and empirical discussion above shows that rules against profit shifting (such as CFC rules and TCRs) are very powerful in principle, and moreover are being widely deployed by nonhaven (residence and source) countries to an increasing degree; Figures 12-15 
show that rules against profit shifting have been substantially strengthened among OECD countries in recent years. ${ }^{31}$ Given the existence of these tax policy instruments, it is arguable that MNCs' use of tax havens relies on the forbearance or even collusion of nonhaven countries. Sufficiently strong CFC rules, TCRs and other rules against profit shifting would eliminate the tax advantages of MNCs' use of havens. Arguably, the tax benefits to MNCs of havens thus exist only to the extent that nonhaven (residence and source) countries refrain from imposing such rules.

There are potential alternative accounts in which nonhaven countries are less complicit in MNCs' use of havens. In the course of the BEPS initiative, the OECD (2013) particularly emphasized unintended interactions among nonhavens' tax laws that enable profit shifting to havens without deliberate facilitation by nonhavens. If this were the entire explanation (and governments were committed to combating profit shifting), however, it might have been expected that provisions responsible for these unintended interactions would have been reformed rather quickly once they came to light, without the need for an extensive multilateral initiative. For example, it is very difficult to understand the persistence of the US CTB provision within the OECD's conceptual framework, especially once its consequences for facilitating foreign tax avoidance should have become very clear to Congress.

The current discussions within the G-20 and OECD Inclusive Framework on a Global AntiBase Erosion (GloBE) proposal (OECD, 2019) reflect this particular perspective. The GloBE proposal seeks to implement a global minimum tax by conferring additional taxing powers (through changes to countries' domestic tax laws and to tax treaties) on residence and source countries to impose taxes on income that has been untaxed or lightly taxed by haven jurisdictions. This approach tends to downplay the role of countries' incentives to use their taxing powers: conferring additional taxing powers is arguably superfluous given that countries already have available powerful tax law instruments to neutralize MNCs' use of havens. In any event, the conferral of such powers does not compel countries to use them, unless there is an effective enforcement mechanism for the global minimum tax.

It is also possible that nonhavens' failure to fully neutralize MNCs' use of havens may represent a policymaking error or oversight. It is hardly the case that governments' policymaking is perfect, even with respect to their chosen objectives. If the critics are correct that MNCs' use havens excessively, however, this explanation would seem to require that such errors are

\footnotetext{
${ }^{31}$ Dharmapala (2019) shows that this change is statistically significant as well as meaningful in terms of magnitude.
} 
systematically in the direction of encouraging MNCs' use of havens, rather than being randomly distributed. It is also possible that governments favor limiting profit shifting to havens, but have many other unrelated priorities that rank higher on their agendas. This would entail, however, that policymakers are failing to respond to what has become a highly salient public concern about MNCs' profit shifting. Such a failure may occur due to political dysfunction, or to the difficulty of mobilizing a sufficiently broad coalition in a political system with a large number of veto players (such as that of the US). However, the extent to which this type of explanation applies more widely among OECD countries (many of which have parliamentary systems with fewer veto players) is unclear.

As discussed above, nonhaven countries' rules against profit shifting are quite widespread and have become substantially stronger in recent years. Yet, they could in principle be even stronger. Why are such rules not used even more extensively than they already are, and what are the implications for the impact of MNCs' use of havens on the welfare of nonhaven countries? There two main possible answers. One is that nonhaven countries use the available tools suboptimally due to a collective action problem: they would collectively be better off with stronger rules (and therefore less MNC use of havens) but no nonhaven country has an incentive to strengthen their rules unilaterally. The other is that MNCs' haven activity serves the interests of nonhaven countries, at least as those interests are construed by their political systems. Nonhaven countries therefore have no reason (unilaterally or even collectively) to further reduce MNCs' haven activity. The former answer is explored in this subsection, while the latter is addressed in the next subsection.

To illustrate the collective action problem that potentially affects the imposition of CFC rules, suppose that country B in the example from Section 3.1 is the residence country of Firm B, an MNC that is symmetric to Firm A in that it earns $\$ 50$ of pretax (and pre-shifting) income in each of countries A and B and also has an affiliate in the haven $\mathrm{H} .{ }^{32}$ Recall that country B imposes a $20 \%$ tax, as does country $\mathrm{A}$, while the haven $\mathrm{H}$ has a zero tax rate. National welfare for countries $\mathrm{A}$ and $\mathrm{B}$ is defined as above, as the sum of tax revenue and the after-tax profits of its resident MNC. Profit shifting by firms A and B entails a cost of $\$ 2$ per country from which profits are shifted to H. If neither country A nor country B imposes a CFC rule, Firm A and Firm B each

\footnotetext{
${ }^{32}$ This is a simplified version of the example developed in Dharmapala (2014b) and also discussed in Desai and Dharmapala (2018).
} 
generate $\$ 100$ of pretax profit, and each shifts all income out to H. As shown in Table 5, each firm has after-tax profit of $\$ 96$ ( $\$ 100$ minus the $\$ 2$ cost of profit-shifting at each affiliate). Tax revenue is zero for each country.

It is clear that neither country has an incentive to unilaterally introduce a CFC rule. For instance, if country A does so, Firm A will no longer have an incentive to shift income to H. It would generate $\$ 100$ of pretax profit, incur zero tax planning costs, and pay tax of $\$ 10$ to $\mathrm{A}$ and $\$ 10$ to B. ${ }^{33}$ This tax payment to country B reduces country A's national welfare, without any offsetting increase in the revenue that country A derives from the local affiliate of firm B. As described in Section 3.1 above and shown in Table 5, country A is clearly worse off by unilaterally introducing a CFC rule (with national welfare of \$90). ${ }^{34}$

However, in this example it is in principle possible for both countries to be better off by both simultaneously imposing CFC rules. Then, each MNC will earn $\$ 100$ of pretax profit, incur zero tax planning costs, and pay $\$ 10$ tax to each country. As shown in Table 5, both countries are better off in this scenario, with national welfare of $\$ 100$ ( $\$ 80$ of after-tax profit for its MNC, plus $\$ 10$ of revenue from its $\mathrm{MNC}$, plus $\$ 10$ of revenue from the other country's MNC). The central reason is that while introducing a CFC involves giving up revenue to the other country, each country also collects more tax from the local affiliate of the other country's MNC due to the other country's CFC rule. In addition, global welfare is higher because the deadweight costs of tax planning are not incurred. Such an outcome requires multilateral cooperation and a mechanism to enforce such cooperation.

With regard to TCRs, the nature of the collective action problem is somewhat different. It is closely related to the basic insight of the theory of tax competition (in which different jurisdictions noncooperatively set tax rates), namely that competition among jurisdictions to attract mobile capital entails that the Nash equilibrium tax rates chosen by these jurisdictions may be suboptimally low from the perspective of global welfare (e.g. Wilson, 1999). For a source country seeking to attract FDI by MNCs, a stronger TCR in effect implies a higher tax rate. Thus, in a

\footnotetext{
${ }^{33}$ Because MNCs' residence is assumed to be fixed, it is not possible in the example for firm A to change its residence to country B. However, such an incentive would exist in reality.

${ }^{34}$ Notwithstanding this incentive structure, the 2017 US tax legislation - generally known as the Tax Cut and Jobs Act (TCJA) - unilaterally introduced a new residence-based minimum tax on US-based MNCs, known as the Global Intangible Low-taxed Income (GILTI) tax. This is not, however, a CFC rule (for instance, it potentially applies to active as well as passive income), and represents a rather idiosyncratic approach in many respects (e.g. Dharmapala, 2018).
} 
standard tax competition framework that is extended to consider the choice of TCRs, the Nash equilibrium TCRs will be weaker than is globally optimal (e.g. Haufler et al., 2018).

The idea that rules against profit shifting are employed suboptimally because of collective actions problems among residence countries (for instance, for CFC rules) and among source countries (for instance, for TCRs) is a conceptually coherent way to make sense of the notion that MNC activity in tax havens may be detrimental to the (collective) welfare of nonhavens, despite the existence in principle of tax law provisions that can neutralize the impact of havens. On the other hand, there are some reasons to doubt that this mechanism predominates in reality. One is the substantial strengthening of CFCs and TCRs over 2000 to 2014 documented in Section 3.2. It is particularly noteworthy that this trend emerged prior to the implementation of the recent G-20 and OECD initiative to foster multilateral cooperation on the issue of Base Erosion and Profit Shifting (BEPS) (OECD, 2015). It appears that the collective action problems - while significant in principle - have in many instances been overcome. In more recent years and into the future, the Inclusive Framework arising from the BEPS initiative (e.g. OECD, 2019) promises what may turn out to be a tectonic shift in terms of greater multilateral cooperation on issues related to profit shifting and tax havens. This implies that collective action problems may become even less significant over time. Moreover, while rules against profit shifting generate spillovers, a relatively small number of major economies substantially (albeit partially) internalize a significant fraction of these spillovers and might be expected to develop mechanisms to implement collectively optimal policies. This is particularly the case for CFC rules, where a relatively small number of major residence countries of MNCs are particularly important.

\section{5) Does MNC Haven Activity Benefit Nonhavens?}

The argument explored in Section 3.4 was that nonhaven countries wish to restrict or eliminate MNCs' haven activity (presumably because it is detrimental to their welfare) and have available in principle the tax law instruments to achieve this aim, but are prevented from doing so by collective action problems. The major alternative view is that MNC activity in havens actually serves the interests of nonhaven countries, at least as those interests are construed by their political systems. In this view, nonhaven countries have available tax law instruments to eliminate MNCs' haven activity, but choose to refrain from using these tools fully because MNCs' tax haven activity is in the (individual and possibly collective) interests of nonhavens. 
How might MNCs' tax haven activities benefit nonhaven countries? A strand of theoretical literature in public finance (e.g. Keen, 2001; Peralta et al., 2006; Hong and Smart, 2010) has specified conditions under which MNCs' tax haven activities may generate such benefits (see also Hines (2007) and Dharmapala (2008) for discussions of this approach). Keen (2001) develops a model that is motivated by preferential tax regimes for foreign investors or specific sectors adopted by some (nonhaven) countries. While the model is not explicitly about tax havens, a nonhaven country's decision to establish a preferential regime for foreign investors is analogous in some respects to, for instance, choosing a weak or nonexistent TCR in order to facilitate foreign MNCs' outbound profit shifting to havens. Keen (2001) introduces into a standard model of tax competition the assumption - which has proven to be an important one in this literature - that capital may be heterogeneous in its mobility across borders. Preferential regimes in principle allow countries to impose lower tax rates for more mobile forms of capital and high tax rates on immobile capital. If preferential regimes are prohibited or infeasible, then countries are constrained to compete by setting a single tax rate for all forms of capital (regardless of mobility). This will result in an inefficiently low tax rate on immobile capital, and forces countries to compete more broadly over the tax rate on all forms of capital. On the other hand, preferential regimes allow countries to tax immobile capital at high rates, while competing only over tax rates imposed on mobile capital. Preferential regimes can thus mitigate tax competition by restricting its effects to a subset of the tax base.

Hong and Smart (2010) develop a model of a small open economy in which the corporate tax serves two functions - to tax the returns to inbound FDI and to tax the rents earned by domestic entrepreneurs. If it were possible to decouple these functions, the country would set a zero tax on inbound FDI (as in a small open economy the burden of this tax is entirely shifted to domestic workers in the form of lower wages), while imposing a relatively high tax rate on domestic entrepreneurs (from whom the government wishes to redistribute to domestic workers). When these functions cannot be decoupled, the existence of tax havens can increase the welfare of nonhaven countries. In particular, a country can choose a weak or nonexistent TCR to facilitate foreign MNCs' outbound profit shifting to havens. This lowers foreign MNCs' effective tax rate and induces more inbound FDI (which makes domestic workers better off). It also allows the country to set a high (nominal) corporate tax rate, which does not (in practical terms) affect MNCs but enables more redistribution from domestic entrepreneurs to domestic workers. 
The crucial assumption in Hong and Smart (2010) that generates the result that the existence of tax havens raises welfare is that the government cannot discriminate overtly between (immobile) domestic entrepreneurs and foreign investors in setting tax rates. While the details of the various models in this literature differ, all assume that there is a political constraint preventing such differential treatment or that there exist limits to the observability of firms' mobility. These assumptions may be viewed by some as arguably ad hoc (although this does not necessarily imply that they lack real-world relevance). If this type of assumption is accepted, it follows that in a wide range of circumstances the existence of havens may increase the welfare of nonhaven countries. The intuition underlying this result extends to a world with multiple nonhaven countries. That is, the value of havens as a means of achieving de facto tax discrimination applies at both the individual and collective level for nonhaven countries.

In this "differential mobility" theory, nonhaven countries optimally use the tax law instruments at their disposal (where optimality entails maximizing both national welfare and global welfare). While their chosen policies limit profit shifting to a significant degree (as documented in Section 3.1), they choose to facilitate some residual amount of profit shifting to havens, to the extent that this promotes their welfare. Indeed, tax havens are important in this view as a means of implementing optimal tax policies that are (by assumption) otherwise impossible to achieve. This view also implies that in a world without havens - for instance, if a multilateral agreement were to require and enforce a relatively high minimum tax rate for all countries - the welfare of nonhavens would be lower as they would be deprived of a means of taxing immobile capital more heavily. Moreover, tax competition may intensify, as tax rate differences across (nonhaven) countries become more important when profit shifting to havens is not possible.

Recently, Weichenrieder and $\mathrm{Xu}$ (2019) develop a critique of the differential mobility theory of havens using a model inspired in part by China's experience with "round-tripping" foreign investment. They argue, in effect, that tax havens (or rather, tax haven secrecy) is a cause of, rather than the solution to, the difficulty of observing the degree of mobility of firms. In their framework, when a nonhaven seeks to impose lower effective taxes on foreign investment, domestic firms may masquerade as foreign (for instance by round-tripping their investment via a foreign haven) and thereby obtain the preferential tax treatment intended for foreign MNCs. This makes it impossible to collect higher revenue from domestic firms, and vitiates the benefit of havens implied by the differential mobility theory. 
While the possibility that domestic firms will masquerade as foreign is real, the assumption in Weichenrieder and $\mathrm{Xu}(2019)$ that the high levels of FDI into China from havens represent taxmotivated round-tripping is questionable. At one time, China granted an explicit tax preference for foreign MNCs. However, this regime ended in 2008, yet havens such as the British Virgin Islands and the Cayman Islands have continued to be prominent sources of FDI into China. Sharman (2012) highlights this puzzle, and argues that tax explanations for this type of round-tripping investment by Chinese entrepreneurs in China are inadequate. Rather, Sharman (2012) develops an alternative explanation based on the idea that the use of havens in this context is driven by governance considerations and the institutional advantages of haven jurisdictions (especially the legal and financial infrastructure that they provide), rather than simply by tax considerations.

The differential mobility theory also assumes that investment is sensitive to the corporate tax rate (or, equivalently, that the corporate tax is an income tax that burdens the normal risk-free return to capital). Indeed, the theory tends to assume a small open economy in which the burden of the corporate income tax is entirely shifted to domestic workers in the form of lower wages, as in Gordon (1986). Recently, it has been argued that the corporate tax has increasingly come to resemble a cash flow tax, i.e. a consumption-type tax that primarily burdens rents generated in the corporate sector (e.g. Fox, 2019). There are two primary reasons for this view. First, the normal or risk-free rate of return is currently quite low. Second, the expensing of intangibles in effect exempts the risk-free return from these investments. If the corporate tax is viewed as a cash-flow tax falling only on rents, then the implications of profit shifting and tax competition are quite different. In particular, profit shifting to havens would generate windfall gains for shareholders of MNCs, without inducing additional investment that could potentially benefit domestic workers.

Even in the scenario where the corporate tax approximates a tax on pure rents, however, it remains possible that nonhaven countries may benefit from profit shifting to havens. Devereux and Griffith $(1998,2003)$ argue that MNCs' decisions about discrete or "lumpy" investment decisions (such as whether to locate a new factory in country X or country Y) depend on the anticipated average tax rate (and hence on the taxation of pure rents); in contrast, decisions about incrementally increasing the level of investment in a country where the firm already has a factory depend on the marginal tax rate and are unaffected by the taxation of pure rents. For a nonhaven country, allowing profit to be shifted to havens (thereby avoiding the tax on pure rents) will reduce the anticipated average tax rate and hence encourage MNCs to undertake discrete investment 
projects. Moreover, this effect may be substantial in magnitude ${ }^{35}$ Admittedly, if the corporate tax were indeed a tax on pure rents - a claim that remains highly contested - the encouragement of profit shifting is less likely to generate collective (as opposed to individual) benefits for nonhaven countries. However, the differential mobility theory of MNCs' haven use would retain some relevance.

Regardless of these theoretical considerations, does the evidence seem to favor the implications of the differential mobility theory? There is abundant empirical evidence that FDI is quite sensitive to taxes (e.g. de Mooij and Ederveen, 2003). This is consistent with countries having an incentive to either lower their tax rates or limit their measures against outward profit shifting to havens in order to attract more FDI (although this evidence does not in itself establish that there are no alternative ways to achieve these objectives than encouraging MNCs' use of havens). Especially relevant is that the empirical literature finds that foreclosing profit shifting opportunities leads to reduced investment. For instance, Büttner, Overesch and Wamser (2018) find that FDI becomes more sensitive to the tax rate when a country introduces a TCR and FDI declines substantially when TCRs are introduced, suggesting that profit shifting opportunities may matter significantly for "real" investment activity by MNCs. De Mooij and Liu (2018) use a global dataset and find that stricter transfer pricing regulations lead to substantial declines in investment by MNCs.

Particularly striking evidence of this nature is provided by Suarez Serrato (2018). Until the relevant provision was repealed by Congress in 1996 (albeit with a 10-year transition period), US tax law provided favorable treatment for the income reported by US firms in Puerto Rico and other US territories. Suarez Serrato (2018) uses establishment-level data to identify US firms that had Puerto Rican establishments (and hence Puerto Rican affiliates to which profits were shifted from the US mainland) and to link these firms to their establishments located in the (mainland) US. He finds that the repeal led to substantial declines in investment and employment in the (mainland) US operations of US firms that previously engaged in profit-shifting to Puerto Rico. These firms tended to be concentrated in certain local regions and labor markets within the US, and Suarez Serrato (2018) finds a long-term decline in employment and wage growth in areas that were more

\footnotetext{
${ }^{35}$ Devereux and Griffith (1998) study a sample of US firms operating in Europe to analyze discrete choices of investment in different countries. They find that a one percentage point increase in a country's average tax rate reduces the probability of a US firm producing in that country by 1.3 percentage points, suggesting that even a tax on pure rents may have sizeable effects on discrete location choices.
} 
exposed to these firms. These results suggest that provisions intended to limit MNCs' profit shifting may have harmful effects on local communities, and provides an explanation for why governments of nonhaven countries may encourage MNCs to shift profits to havens.

The argument in this section has challenged the conventional view that MNC activity in tax havens reduces nonhaven countries' welfare by eroding their tax base. As discussed above, the conventional view does not take full account of the fact that nonhavens have long had available tax law provisions that effectively neutralize the tax consequences of havens. It is indeed true that MNCs' haven activity, among other things, erodes nonhavens' tax bases. However, it arguably does so with the consent and encouragement of nonhavens themselves, which seek for example to attract greater inbound investment or to encourage their resident MNCs to avoid foreign taxes. In this sense, MNCs' haven activity serves the interests of major nonhaven countries; if it did not, presumably such activity would not be permitted. The real (and more difficult) questions concern whether MNCs' haven activity promotes nonhavens' "true" welfare, or merely their interests as refracted through the prism of various political distortions. There are reasonable grounds for either view. However, the conventional discourse tends to obscure the relevant questions that should be addressed.

\section{4) How Much MNC Profit is Shifted to Tax Havens? \\ 4.1) Estimates of the Magnitude of Profit Shifting}

At the same time that MNCs' profit shifting activities have become the subject of increased interest among the public, a growing empirical literature has sought to estimate the magnitude of profit shifting. These studies can - broadly speaking - be divided into those using microeconometric techniques applied to affiliate-level microdata and those using aggregate (typically country-level) data. Among the former category, a particularly influential approach is based on Hines and Rice (1994). Its basic premise is that the observed pretax profit of an MNC affiliate represents the sum of "true" profits (generated using capital and labor inputs, which are included in the regression analysis to predict the affiliate's counterfactual profit, absent shifting) and "shifted" profits. Differences between observed and counterfactual profits are attributed to profit shifting. ${ }^{36}$

\footnotetext{
${ }^{36}$ Several alternative microeconometric approaches to the estimation of profit shifting have also been developed. For instance, Dharmapala and Riedel (2013) analyze the impact of industry-level shocks to MNC parents' income and
} 
The Hines-Rice approach is typically implemented using a log-linear specification that is used to estimate a semi-elasticity (i.e. the percentage change in reported profit associated with a one percentage point change in the tax rate difference across countries), controlling for capital and labor inputs and using affiliate fixed effects to absorb unobserved heterogeneity at the affiliate level. Dharmapala (2014a) surveys the extensive literature that has used this approach. Recent estimates using affiliate-level data (such as the Amadeus and Orbis databases compiled by the Bureau van Dijk) have found the magnitude of profit shifting to be considerably smaller than that found in earlier studies using country-level data. A representative consensus estimate from the literature is a semi-elasticity of reported profit with respect to the tax rate differential across countries of 0.8 (see in particular the meta-regression study of Heckemeyer and Overesch (2017)). This entails that a 10 percentage point increase in the tax rate difference between an affiliate and its parent (e.g. because the tax rate in the affiliate's country falls from $35 \%$ to $25 \%$ ) would increase the pretax profit reported by the affiliate by $8 \%$ (for example, from $\$ 100,000$ to $\$ 108,000$ ). A more recent meta-regression analysis (Beer, de Mooij and Liu, 2019) uses a larger number of underlying estimates (including those using aggregate data) and finds a somewhat higher - albeit comparable - semi-elasticity of 1. For studies using data for the most recent years, however, the semi-elasticity tends to be larger (as high as 1.5).

In general, the micro literature tends to find magnitudes of profit shifting that are substantially smaller than suggested by the aggregate data reviewed in Section 2.1, and this apparent disjuncture has given rise to a debate as to how to best measure profit shifting. ${ }^{37}$ As discussed in Section 2 above, the aggregate data may be misleading in many respects, for instance due to the double counting of the income of holding companies located in havens. On the other hand, critics of the microeconometric studies (e.g. Clausing, 2016) highlight the limited coverage of tax haven affiliates in the affiliate-level datasets. ${ }^{38}$ Even when haven affiliate data exists,

compare how these shocks are reflected in the reported earnings of high-tax and low-tax foreign affiliates. There is also an emerging literature that uses a bunching approach to examine the tendency of MNC affiliates - relative to domestic firms - to report zero profits (e.g. Bilicka, 2019; Dharmapala and Hebous, 2017). However, the Hines-Rice approach sketched above is the most widely used one to date.

${ }^{37}$ For example, assuming that nonhaven countries have a tax rate of $25 \%$ while havens have a zero tax rate, the 0.8 semi-elasticity discussed above implies that less than $20 \%$ of MNCs' foreign profits are shifted to tax havens (Dharmapala, 2014a).

${ }^{38}$ Dowd, Landefeld and Moore (2017) use US corporate tax return data for 2002-2010 that includes extensive information on tax haven - as well as other - CFCs of US-based MNC groups. They also use an empirical specification that allows for nonlinearities in the effect of the tax variable on the log of profits. Using this approach, they find a substantially larger semi-elasticity of reported profits with respect to the tax variable for zero-tax jurisdictions. Note, 
identification relies on within-affiliate changes over time in the tax rate (or in the tax differential relative to other affiliates), so profit shifting to tax haven affiliates with (unchanging) zero tax rates may not be fully captured by this approach. Profit shifting may also be relatively insensitive to small changes in the tax differential in the presence of fixed costs of tax planning, even when the tax rate differential between the MNC parent's country and the haven changes due to reforms in the former. In essence, critics argue that part of the profit shifting phenomenon may be embedded in the affiliate fixed effect.

These concerns have led to a revival of studies using aggregate data, generally finding large magnitudes of profit shifting. For instance, Tørsløv, Wier and Zucman (2018) use newly available macroeconomic data on tax havens (and in particular what are known as foreign affiliate statistics) to infer the specific nonhaven countries from which income reported in havens has arguably been shifted. Their approach suggests that about $40 \%$ of the foreign profits of MNCs are shifted to havens. ${ }^{39}$

\section{2) Micro versus Macro Approaches and the Conceptualization of Profit Shifting}

Differences in data coverage with respect to havens or the double counting of haven affiliates' income in aggregate datasets may account for some of the differences in the findings of the micro and macro literatures. However, it also appears that there are some fundamental conceptual differences between the notions of profit shifting underlying these approaches. In particular, by controlling for capital and labor inputs and other affiliate characteristics, micro estimates take as given the location of productive assets. Micro studies typically do not explicitly control for the location of intangible assets; however, to the extent that the location of these assets is time-invariant (for instance, always being located in lower-tax jurisdictions), this would be largely absorbed by affiliate fixed effects. Given the location of productive assets, the micro approach seeks to estimate the extent of profit shifting, viewed as a form of tax avoidance (i.e. a reduction in the worldwide tax burden of the MNC group, with little or no substantive economic impact on its operations).

\footnotetext{
however, that there are various limitations of this dataset. The consolidation of branches and CTB entities implies that profits of nonhaven entities are attributed to haven affiliates. Financial data is often missing from the informational tax returns on which the analysis is based, and the sample is restricted to CFCs with positive profit (as is also true of much of the prior literature).

${ }^{39}$ Blouin and Robinson (2019) discuss how the double counting problem discussed in Section 2.1 above may bias these types of estimates upwards when they use aggregate data on US MNCs. Dyreng and Hanlon (2019) argue that the large estimates of the magnitude of MNCs' profit shifting found using aggregate data are implausible in the light of the effective foreign tax rates reported in firms' financial statements.
} 
The location of tangible capital (such as factories and machinery) is influenced by tax rate differences across countries, as suggested by the large empirical literature finding real investment by MNCs to be sensitive to taxes (e.g. de Mooij and Ederveen, 2003). However, an MNC choosing to build a factory in a lower-tax rather than higher-tax location is classified in the parlance of public finance theory as a behavioral (or "real") response to taxation, rather than as tax avoidance. Recalling the definition of tax avoidance in Section 2 above as "the lawful reduction of tax obligations, while maintaining the same substantive economic outcome" (Dharmapala, 2017, p. $\mathrm{xv}$ ), it is clear that the MNC's substantive economic outcome is not the same when it makes such a tax-motivated decision, whenever the higher-tax location is preferable on nontax grounds. For instance, the quality of physical infrastructure may be lower in the lower-tax location, and the MNC would have to trade off this disadvantage against the tax benefits of the lower-tax location. These nontax costs associated with the lower-tax location can be characterized as nontax frictions that limit the tax-optimality of the MNCs' real investment choices.

Behavioral responses to tax differences give rise to distortions - factories end up being located in the "wrong" place from the perspective of maximizing global (pretax) social welfare. Tax avoidance (including profit shifting) is fundamentally different because, by assumption, there are no nontax frictions that change substantive economic outcomes. Consider, for instance, the interest stripping strategy described earlier in Section 2. The placement of debt in one affiliate rather than another has very limited substantive effects on the worldwide MNC group. This does not imply that tax avoidance does not have social costs, as resources may be used in the process of tax planning. However, this social cost is quite different in nature from the social costs of behavioral responses to taxation. ${ }^{40}$ Figure 16 illustrates the difference between tax avoidance and behavioral responses to taxation, in terms of the importance of nontax frictions. When nontax frictions are minimal, as with interest stripping, (lawful) tax-motivated activities are best characterized as tax avoidance. When nontax frictions are substantial, as with the location of factories, tax-motivated choices are most usefully viewed not as tax avoidance but as behavioral responses to taxes.

In taking as given the location of productive assets, the micro approach seeks to isolate the amount of profit shifting per se (i.e. of MNCs' cross-border tax avoidance via channels such as interest stripping and strategic transfer pricing). Properly understood, this approach does not aim

\footnotetext{
${ }^{40}$ As discussed earlier, tax planning is also limited by anti-avoidance provisions in the tax law
} 
to capture the disproportionate location of intangible assets and holding companies in havens (except to the extent that these change over time in response to tax differentials). That these effects are typically absorbed by the affiliate fixed effects is thus not a shortcoming of the approach. On the other hand, macro approaches that rely on aggregate data tend to presume that these locational choices are themselves a form of tax avoidance. An illustration is provided by Tørsløv, Wier and Zucman (2018). They compare profit-to-wage ratios across local and foreign-owned firms in different countries, defining the relevant capital stock as consisting only of tangible assets. Thus, havens in which affiliates own substantial intangible assets appear in their analysis to have a dramatically inflated profit-to-wage ratio for foreign affiliates. ${ }^{41}$

This presumption may, however, be problematic. R\&D is frequently financed by haven affiliates, for instance under the cost-sharing arrangements that are important in US transfer pricing law, even when researchers are located in nonhaven countries. This implies that the profits from intangible assets (or some portion thereof) will appear in the profits-to-wages ratio of haven affiliates while the wages of the relevant R\&D workers will not. Yet, the haven affiliate quite legitimately owns a share of the intangible asset corresponding to its share of the cost. It is possible to critique such cost-sharing arrangements as being artificial. However, tax law in general tends to respect taxpayers' formal choices, and cost-sharing arrangements are blessed by the tax law of nonhaven countries such as the US. They are also consistent with basic income tax principles requiring the matching of the location of income and deductions (thereby ensuring alignment between the tax rates applicable to the income from intangible assets and to the deductions for their costs). For instance, if a haven affiliate finances $50 \%$ of the cost of an asset, $50 \%$ of its cost is deducted at the haven's tax rate, just as $50 \%$ of the income from that asset is taxed at the haven's tax rate.

This discussion raises a wider point about the extent to which MNCs' decisions about the location of IP and of holding companies are purely tax-motivated and whether nontax frictions are significant. In other words, where do these choices lie along the spectrum illustrated in Figure 16 ? Ultimately, the extent of nontax frictions - and hence whether these types of locational choices should be viewed as tax avoidance or as behavioral responses to tax rate differences - is an empirical question. The evidence discussed in Section 2 above for holding companies (e.g. Desai, Foley and Hines, 2006) suggests that, while the location of holding companies may be highly tax-

\footnotetext{
${ }^{41}$ Their analysis also ignores the role of financial capital, but this issue is not emphasized here.
} 
motivated, the substantial fraction of holding companies in nonhaven jurisdictions implies the existence of significant nontax frictions. Moreover, there is considerable direct evidence for nontax motivations in MNCs' use of haven affiliates. ${ }^{42}$ In addition, MNCs' locational choices among zerotax countries tend not to be random, but are influenced by nontax considerations. Better governance institutions are strongly associated with higher levels of MNC activity (e.g. Wei, 2000; Dharmapala and Hines, 2009), suggesting the significance of nontax frictions of an institutional nature.

As discussed in Section 2, these nontax frictions may include legal infrastructure and the availability of legal and business expertise in different locations. Historically, there has been great emphasis on physical infrastructure as a determinant of FDI. More recently, legal and business infrastructure has grown in significance for $\mathrm{MNC}$ activity. If the conception of behavioral responses is limited to the location of tangible assets, it is possible that there will be a purely mechanical tendency for what is commonly viewed as profit shifting to grow over time. Arguably, the notion of behavioral response should evolve to reflect the growing significance of legal and business (rather than physical) infrastructure in MNC activity. Of course, none of this is intended to suggest that MNCs' use of havens is not tax-motivated. The question here - highlighted by Figure 16 - is whether there also exist nontax frictions that may make MNCs' locational choices for holding companies and IP more analogous to a behavioral response to taxation than is generally appreciated. This question is an important one for future analysis.

\section{5) Conclusion}

MNCs' use of tax havens has attracted increasing attention and scrutiny in recent years, and is now more relevant than ever in the light of policy initiatives such as the GloBE proposal for a global minimum tax rate on MNCs' profits (OECD, 2019). This paper provides an overview of the current state of knowledge within the academic literature on this topic. The empirical evidence reviewed above is consistent with MNCs' disproportionate use of havens as locations for holding companies, IP and financial activities. However, there is also considerable evidence of frictions

\footnotetext{
${ }^{42}$ For example, as noted earlier, Sharman (2012) explains the prominent role of havens in FDI into China (even after the abolition of preferential tax treatment for foreign investment) by governance considerations and the legal and institutional advantages of the haven jurisdictions. Some Chinese entrepreneurs are believed to establish parent firms in jurisdictions such as the British Virgin Islands because they wish to issue dual-class stock (where voting rights differ across different classes of stock). It is unclear whether Chinese company law respects dual-class stock, and so firms can avoid this legal uncertainty by incorporating in a haven jurisdiction that clearly permits dual-class stock.
} 
that limit MNCs' use of havens. The standard view that is widespread in public discourse is that MNCs' use of havens harms nonhaven countries by eroding their tax base. This paper develops an alternative perspective based on the argument that MNCs' use of havens relies crucially on forbearance or active facilitation by nonhavens, as the latter have available a variety of powerful tax law instruments to neutralize the impact of MNCs' use of havens. The failure to deploy these instruments as fully as possible is arguably a deliberate policy choice, due either to collective action problems among nonhavens or to the possibility that in certain circumstances MNCs' use of havens increases the welfare of nonhaven countries. The paper also discusses how the distinction commonly made in public finance theory between tax avoidance and behavioral responses to taxation can illuminate current debates about the magnitude and implications of MNCs' profit shifting to havens.

\section{References}

Altshuler, Rosanne, and Harry Grubert (2005) "The three parties in the race to the bottom: Host governments, home governments and multinational companies" Florida Tax Review, 7: 137-209.

Beer, Sebastian, Ruud A. de Mooij, and Li Liu (2019) “International Corporate Tax Avoidance: A Review of the Channels, Magnitudes, and Blind Spots" Journal of Economic Surveys, forthcoming.

Bennedsen, Morten, and Stefan Zeume (2017) "Corporate tax havens and transparency" Review of Financial Studies 31, no. 4: 1221-1264.

Bilicka, Katarzyna Anna (2019) "Comparing UK tax returns of foreign multinationals to matched domestic firms" American Economic Review 109, no. 8: 2921-53.

Blouin, Jennifer, and Leslie Robinson (2019) "Double counting accounting: How much profit of multinational enterprises is really in tax havens?" Working Paper, available at: https://papers.ssrn.com/sol3/papers.cfm?abstract_id=3491451

Braun, Julia, and Alfons J. Weichenrieder (2015) "Does Exchange of Information between Tax Authorities Influence Multinationals' Use of Tax Havens?" ZEW-Centre for European Economic Research Discussion Paper 15-015.

Büttner, Thiess, Michael Overesch, Ulrich Schreiber and Georg Wamser (2012) "The Impact of Thin-Capitalization Rules on the Capital Structure of Multinational Firms" Journal of Public Economics 96 (11-12): 930-938. 
Büttner, Thiess, Michael Overesch, and Georg Wamser (2016) "Restricted interest deductibility and multinationals' use of internal debt finance" International Tax and Public Finance, 23(5): 785-797.

Büttner, Thiess, Michael Overesch, and Georg Wamser (2018) "Anti profit-shifting rules and foreign direct investment” International Tax and Public Finance, 25(3): 553-580.

Casi, Elisa, Christoph Spengel, and Barbara Stage (2018) "Cross-border tax evasion after the common reporting standard: Game over?” ZEW-Centre for European Economic Research Discussion Paper 18-036.

Clausing, Kimberly A. (2016) "The Effect of Profit Shifting on the Corporate Tax Base in the United States and Beyond" National Tax Journal 69, no. 4: 905-934.

Clifford, Sarah (2019) "Taxing multinationals beyond borders: financial and locational responses to CFC rules" Journal of Public Economics 173: 44-71.

De Mooij, Ruud A. and Sjef Ederveen (2003) “Taxation and Foreign Direct Investment: A Synthesis of Empirical Research" International Tax and Public Finance 10 (6): 673-93.

De Mooij, Ruud A., and Li Liu (2018) “At A Cost: the Real Effects of Transfer Pricing Regulations" International Monetary Fund Working Paper No. 18/69.

Desai, Mihir A. and Dhammika Dharmapala (2006) "Corporate Tax Avoidance and High-Powered Incentives" Journal of Financial Economics 79 (1), 145-179.

Desai, Mihir A. and Dhammika Dharmapala (2008) "Tax and Corporate Governance: An Economic Approach" in Wolfgang Schön (ed.) Tax and Corporate Governance, Springer, pp. 13-30.

Desai, Mihir A. and Dhammika Dharmapala (2009a) "Corporate Tax Avoidance and Firm Value" Review of Economics and Statistics 91 (3), 537-546.

Desai, Mihir A., and Dhammika Dharmapala. (2009b) "Earnings management, corporate tax shelters, and book-tax alignment" National Tax Journal 62, no. 1: 169-186.

Desai, Mihir A., and Dhammika Dharmapala (2015) "Interest deductions in a multijurisdictional world" National Tax Journal 68, no. 3: 653-681.

Desai, Mihir A., and Dhammika Dharmapala (2018) "Revisiting the uneasy case for corporate taxation in an uneasy world" Journal of the British Academy 6, no. s1: 247-84.

Desai, Mihir A., C. Fritz Foley, and James R. Hines, Jr. (2006) “The Demand for Tax Haven Operations” Journal of Public Economics 90 (3), 513-531.

Devereux, Michael P., and Rachel Griffith (1998) “Taxes and the Location of Production: 
Evidence from a Panel of US Multinationals.” Journal of Public Economics 68 (3): 33567.

Devereux, Michael P., and Rachel Griffith (2003) "Evaluating Tax Policy for Location Decisions." International Tax and Public Finance 10 (2): 107-26.

Dharmapala, Dhammika (2008) "What problems and opportunities are created by tax havens?" Oxford Review of Economic Policy 24, no. 4: 661-679.

Dharmapala, Dhammika (2014a) "What Do We Know About Base Erosion and Profit Shifting? A Review of the Empirical Literature" Fiscal Studies 35 (4), 421-448.

Dharmapala, Dhammika (2014b) "Base Erosion and Profit Shifting: A Simple Conceptual Framework” CESifo DICE Report 12 (4), 8-14.

Dharmapala, Dhammika (2016) "Cross-border tax evasion under a unilateral FATCA regime” Journal of Public Economics 141: 29-37.

Dharmapala, Dhammika, ed. (2017) The Economics of Tax Avoidance and Evasion, Cheltenham: Edward Elgar.

Dharmapala, Dhammika (2018) "The Consequences of the Tax Cut and Jobs Act's International Provisions: Lessons from Existing Research” National Tax Journal, Vol. 71, pp. 707728.

Dharmapala, Dhammika (2019) "Profit Shifting in a Globalized World" American Economic Association Papers and Proceedings, Vol. 109, 2019, pp. 488-492.

Dharmapala, Dhammika, C. Fritz Foley and Kristin J. Forbes (2011) "Watch What I Do, Not What I Say: The Unintended Consequences of the Homeland Investment Act." Journal of Finance 66 (3): 753-87.

Dharmapala, Dhammika and Shafik Hebous (2017) "A Bunching Approach to Measuring Multinational Profit Shifting” Working Paper.

Dharmapala, Dhammika and James R. Hines, Jr. (2009) "Which Countries Become Tax Havens?" Journal of Public Economics 93 (9-10), 1058-1068.

Dharmapala, Dhammika and Nadine Riedel (2013) "Earnings Shocks and Tax-Motivated Income Shifting: Evidence from European Multinationals" Journal of Public Economics 97, 95107.

Dischinger, Matthias, and Nadine Riedel (2011) "Corporate Taxes and the Location of Intangible Assets within Multinational Firms” Journal of Public Economics 95 (7-8): 691-707.

Dowd, Tim., Paul Landefeld and Anne Moore (2017) "Profit shifting of US multinationals" 
Journal of Public Economics, 148: 1-13.

Dyreng, Scott and Michelle Hanlon (2019) "Tax Avoidance and Multinational Firm Behavior" Working paper, prepared as part of the Brookings Institution project on "Multinational Corporations in a Changing Global Economy."

Fox, Edward G. (2019) "Does Capital Bear the US Corporate Tax After All? New Evidence from Corporate Tax Returns" Journal of Empirical Legal Studies, forthcoming.

Ginsburg, Tom and Aziz Huq (2018) "How to lose a constitutional democracy" UCLA Law Review, 65: 78-169.

Gordon, Roger H. (1986) "Taxation of Investment and Savings in a World Economy" American Economic Review 76, no. 5: 1086-1102.

Gresik, Thomas A., Dirk Schindler, and Guttorm Schjelderup (2017) "Immobilizing corporate income shifting: Should it be safe to strip in the harbor?" Journal of Public Economics 152: 68-78.

Gumpert, Anna, James R. Hines Jr, and Monika Schnitzer. (2016) "Multinational firms and tax havens" Review of Economics and Statistics 98, no. 4: 713-727.

Haufler, Andreas, Mohammed Mardan and Dirk Schindler (2018) "Double Tax Discrimination to Attract FDI and Fight Profit Shifting: The Role of CFC Rules" Journal of International Economics 114, 25-43.

Heckemeyer, Jost H., and Michael Overesch (2017) "Multinationals' profit response to tax differentials: Effect size and shifting channels" Canadian Journal of Economics, 50, no. 4: 965-994.

Hong, Qing, and Michael Smart (2010) "In praise of tax havens: International tax planning and foreign direct investment" European Economic Review 54, no. 1: 82-95.

Hines, James R., Jr. (2010) “Treasure Islands” Journal of Economic Perspectives 24 (4), 103-125.

Hines, James R., Jr. and Eric M. Rice (1994) "Fiscal Paradise: Foreign Tax Havens and American Business" Quarterly Journal of Economics 109 (1), 149-182.

Keen, Michael (2001) "Preferential regimes can make tax competition less harmful" National Tax Journal, 54, no. 4: 757-762.

Mardan, Mohammed (2017) "Why countries differ in thin capitalization rules: The role of financial development" European Economic Review 91: 1-14.

Markle, Kevin, and Leslie Robinson (2012) "Tax haven use across international tax regimes" Working Paper. 
O’Donovan, James, Hannes F. Wagner, and Stefan Zeume (2019) "The value of offshore secrets: Evidence from the Panama Papers" Review of Financial Studies 32, no. 11: 4117-4155.

OECD (2013), Addressing Base Erosion and Profit Shifting, Paris: OECD.

OECD (2015) Explanatory Statement OECD/G20 Base Erosion and Profit Shifting Project, Paris: OECD.

OECD (2019) Public Consultation Document: Global Anti-Base Erosion Proposal (“GloBE”) Pillar Two, Paris: OECD.

Peralta, Susana, Xavier Wauthy, and Tanguy Van Ypersele (2006) "Should countries control international profit shifting?” Journal of International Economics 68, no. 1: 24-37.

Prettl, Axel (2018) "Profit Shifting and Controlled Foreign Corporation Rules - The thin bridge between corporate tax systems" Working paper, available at: https://papers.ssrn.com/sol3/papers.cfm?abstract id=3102553

Rose, Andrew K., and Mark M. Spiegel (2007) “Offshore financial centres: Parasites or symbionts?” Economic Journal 117, no. 523: 1310-1335.

Ruf, Martin, and Dirk Schindler (2015) "Debt shifting and thin-capitalization rules-German experience and alternative approaches” Nordic Tax Journal 2015, no. 1: 17-33.

Ruf, Martin, and Alfons J. Weichenrieder (2012) "The taxation of passive foreign investment: Lessons from German experience” Canadian Journal of Economics, 45, no. 4: 1504-1528.

Sharman, Jason Campbell (2012) "Chinese capital flows and offshore financial centers" The Pacific Review 25, no. 3: 317-337.

Suarez Serrato, Juan Carlos (2018) "Unintended Consequences of Eliminating Tax Havens" NBER Working Paper 24850.

Tørsløv, Thomas R., Ludvig S. Wier and Gabriel Zucman (2018) “The Missing Profits of Nations" NBER Working Paper 24701.

Wei, Shang-Jin (2000) "How taxing is corruption on international investors?" Review of Economics and Statistics 82, no. 1: 1-11.

Weichenrieder, Alfons J. and Fangying Xu (2019) "Are tax havens good? Implications of the crackdown on secrecy." Journal of Economics (previously Zeitschrift für Nationalökonomie) 127, no. 2: 147-160.

Wilson, John Douglas (1999) “Theories of tax competition” National Tax Journal 52, no. 2: 269270. 
Table 1: The Share of US MNCs' Foreign Activity in Haven Jurisdictions (MajorityOwned Foreign Affiliates, 2016)

\begin{tabular}{|l|c|c|c|}
\hline \multicolumn{1}{|c|}{ Type of Activity } & $\begin{array}{c}\text { All Foreign } \\
\text { Countries }\end{array}$ & Havens & $\begin{array}{c}\text { \% of Activity in } \\
\text { Havens }\end{array}$ \\
\hline Number of Affiliates & 34,881 & 7,441 & $21.33 \%$ \\
\hline Total Assets (\$ millions) & $25,226,581$ & $8,636,399$ & $34.24 \%$ \\
\hline $\begin{array}{l}\text { Net Plant, Property and } \\
\text { Equipment (\$ millions) }\end{array}$ & $1,367,094$ & 184,686 & $13.51 \%$ \\
\hline $\begin{array}{l}\text { Capital Expenditures (\$ } \\
\text { millions) }\end{array}$ & 199,478 & 28,261 & $14.17 \%$ \\
\hline Sales (\$ millions) & $5,781,264$ & $1,420,096$ & $24.56 \%$ \\
\hline Net Income (\$ millions) & $1,015,559$ & 503,302 & $49.56 \%$ \\
\hline Value Added (\$ millions) & $1,300,419$ & 231,136 & $17.77 \%$ \\
\hline R \& D Activity (\$ millions) & 53,451 & 7,423 & $13.89 \%$ \\
\hline $\begin{array}{l}\text { Employee Compensation } \text { (\$ } \\
\text { millions) }\end{array}$ & 599,410 & 54,737 & $9.13 \%$ \\
\hline $\begin{array}{l}\text { Number of Employees } \\
\text { thousands) }\end{array}$ & $14,256.1$ & 711 & $4.99 \%$ \\
\hline
\end{tabular}

Note: Author's calculations, using aggregate country-level data for 2016 on the foreign activities of US MNCs from the US Bureau of Economic Analysis (BEA), available at: www.bea.gov. These calculations are based on the BEA's preliminary 2016 data, which may potentially change when revised by the BEA. Tax havens are defined using the classification in Dharmapala and Hines (2009), with some minor updates described in the text. 
Table 2: Haven Jurisdictions' Shares of Selected Types of Income (Majority-Owned Foreign Affiliates of US MNCs, 2014 Benchmark Survey)

\begin{tabular}{|l|c|c|c|}
\hline \multicolumn{1}{|c|}{ Income Category } & $\begin{array}{c}\text { All Foreign } \\
\text { Countries }\end{array}$ & Havens & $\begin{array}{c}\text { \% Reported in } \\
\text { Havens }\end{array}$ \\
\hline $\begin{array}{l}\text { Income from equity } \\
\text { investments in foreign affiliates } \\
\text { (\$ millions) }\end{array}$ & 718,790 & 356,226 & $49.56 \%$ \\
\hline $\begin{array}{l}\text { Dividends or remitted profits } \$ \\
\text { millions) }\end{array}$ & 519,039 & 193,667 & $37.31 \%$ \\
\hline Capital gains/losses (\$ millions) & 10,251 & 10,429 & $101.74 \%$ \\
\hline $\begin{array}{l}\text { Royalties and License Fees (\$ } \\
\text { millions) }\end{array}$ & 67,786 & 44,129 & $65.10 \%$ \\
\hline $\begin{array}{l}\text { Royalties and License Fees } \\
\text { from US Sources (\$ millions) }\end{array}$ & 6,040 & 1,736 & $28.74 \%$ \\
\hline $\begin{array}{l}\text { Royalties and License Fees } \\
\text { from non-US Sources (\$ } \\
\text { millions) }\end{array}$ & 61,746 & 38,666 & $62.62 \%$ \\
\hline Interest Receipts (\$ millions) & 201,474 & 57,535 & $28.56 \%$ \\
\hline $\begin{array}{l}\text { Net Income from Finance and } \\
\text { Insurance Activities (\$ } \\
\text { millions) }\end{array}$ & 161,243 & 84,077 & $52.14 \%$ \\
\hline
\end{tabular}

Note: Author's calculations, using aggregate country-level data for 2014 benchmark survey on the foreign activities of US MNCs from the US Bureau of Economic Analysis (BEA), available at: www.bea.gov. The BEA's benchmark surveys provide more detailed information and more extensive coverage than its annual surveys. Tax havens are defined using the classification in Dharmapala and Hines (2009), with some minor updates described in the text. 
Table 3: Haven Jurisdictions' Shares of Selected Types of Income (Majority-Owned Foreign Affiliates of US MNCs, 2009 Benchmark Survey)

\begin{tabular}{|l|c|c|c|}
\hline \multicolumn{1}{|c|}{ Income Category } & $\begin{array}{c}\text { All Foreign } \\
\text { Countries }\end{array}$ & Havens & $\begin{array}{c}\text { \% Reported in } \\
\text { Havens }\end{array}$ \\
\hline $\begin{array}{l}\text { Income from equity } \\
\text { investments in foreign affiliates } \\
\text { (\$ millions) }\end{array}$ & 514,677 & 166,473 & $32.35 \%$ \\
\hline $\begin{array}{l}\text { Dividends or remitted profits (\$ } \\
\text { millions) }\end{array}$ & 467,399 & 173,455 & $37.11 \%$ \\
\hline Capital gains/losses (\$ millions) & $-29,140$ & -365 & $1.25 \%$ \\
\hline $\begin{array}{l}\text { Royalties and License Fees } \\
\text { from non-US Sources (\$ } \\
\text { millions) }\end{array}$ & 36,629 & 22,439 & $61.26 \%$ \\
\hline \begin{tabular}{l} 
Interest Receipts (\$ millions) \\
\hline $\begin{array}{l}\text { Net Income from Finance and } \\
\text { Insurance Activities (\$ } \\
\text { millions) }\end{array}$
\end{tabular} & 224,282 & 52,678 & $23.49 \%$ \\
\hline
\end{tabular}

Note: Author's calculations, using aggregate country-level data for 2014 benchmark survey on the foreign activities of US MNCs from the US Bureau of Economic Analysis (BEA), available at: www.bea.gov. The BEA's benchmark surveys provide more detailed information and more extensive coverage than its annual surveys. Note that royalties and license fees from US sources are not reported for 2009. Tax havens are defined using the classification in Dharmapala and Hines (2009), with some minor updates described in the text. 
Table 4: Composition of the Total Income of Haven and Nonhaven affiliates (MajorityOwned Foreign Affiliates of US MNCs, 2009 and 2014 Benchmark Surveys)

\begin{tabular}{|l|c|c|c|c|}
\hline & \multicolumn{2}{|c|}{2009} & \multicolumn{2}{c|}{2014} \\
\hline Income Category & $\begin{array}{c}\text { Haven } \\
\text { Affiliates }\end{array}$ & $\begin{array}{c}\text { Nonhaven } \\
\text { Affiliates }\end{array}$ & $\begin{array}{c}\text { Haven } \\
\text { Affiliates }\end{array}$ & $\begin{array}{c}\text { Nonhaven } \\
\text { Affiliates }\end{array}$ \\
\hline $\begin{array}{l}\text { Income from equity } \\
\text { investments in foreign } \\
\text { affiliates (\$ millions) }\end{array}$ & $13.48 \%$ & $8.31 \%$ & $18.35 \%$ & $6.58 \%$ \\
\hline $\begin{array}{l}\text { Capital gains/losses (\$ } \\
\text { millions) }\end{array}$ & $-0.03 \%$ & $-0.69 \%$ & $0.54 \%$ & $0.00 \%$ \\
\hline $\begin{array}{l}\text { Royalties and License Fees (\$ } \\
\text { millions) }\end{array}$ & $1.82 \%$ & $0.34 \%$ & $2.27 \%$ & $0.43 \%$ \\
\hline Interest Receipts (\$ millions) & $4.27 \%$ & $4.09 \%$ & $2.96 \%$ & $2.61 \%$ \\
\hline
\end{tabular}

Note: Author's calculations, using aggregate country-level data for the 2009 and 2014 benchmark surveys on the foreign activities of US MNCs from the US Bureau of Economic Analysis (BEA), available at: www.bea.gov. The BEA's benchmark surveys provide more detailed information and more extensive coverage than its annual surveys. Tax havens are defined using the classification in Dharmapala and Hines (2009), with some minor updates described in the text.

Table 5: Payoffs of Countries A and B

Country B

CFC Rule No CFC Rule

\begin{tabular}{|c|c|c|c|}
\hline \multirow[t]{2}{*}{ Country A } & CFC Rule & 100,100 & 90,106 \\
\hline & No CFC Rule & 106,90 & 96,96 \\
\hline
\end{tabular}

Source: Dharmapala (2014b) 
Figure 1: The Share of US MNCs' Foreign Activity in Haven Jurisdictions (MajorityOwned Foreign Affiliates, 2016)

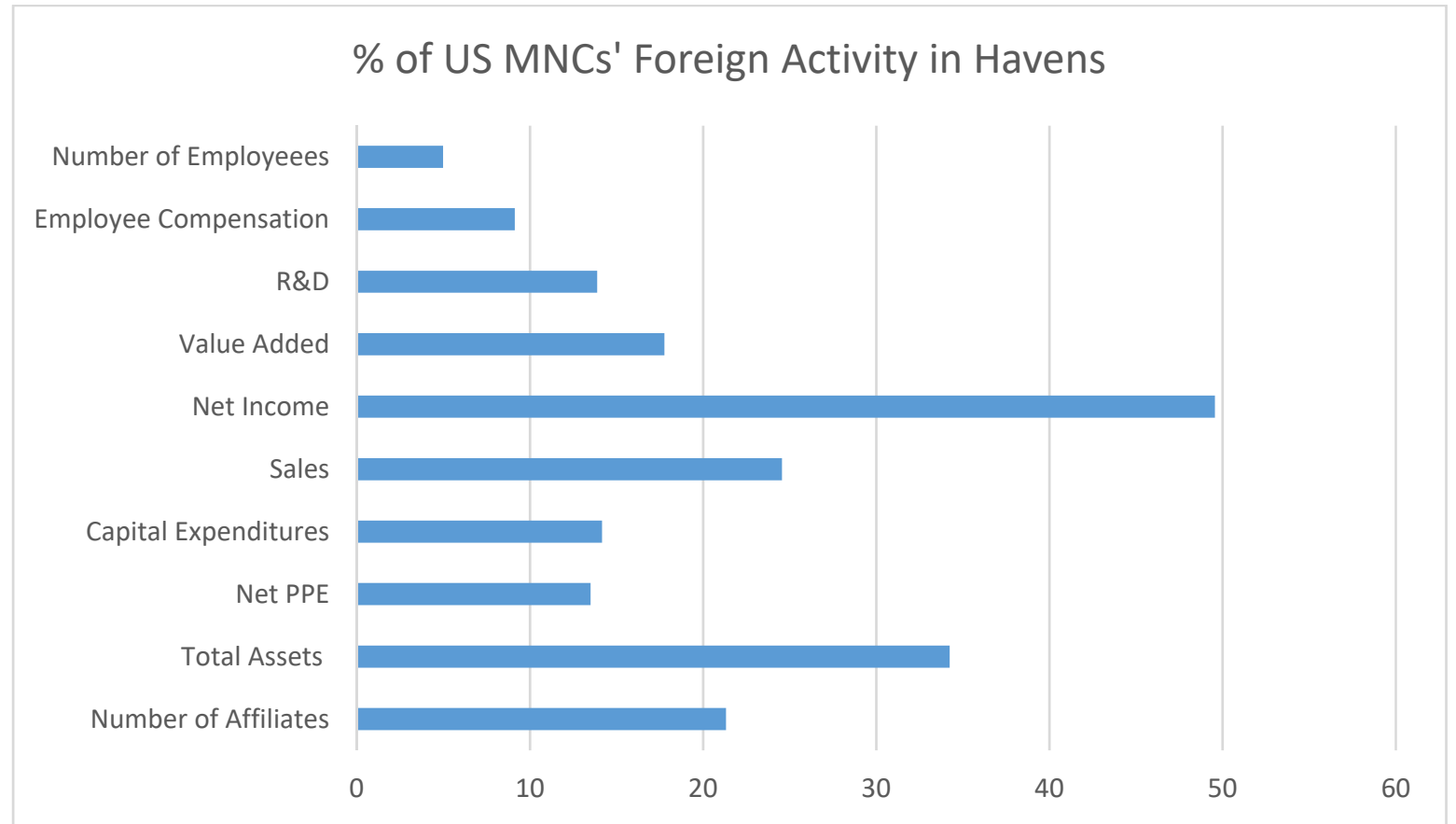

Note: Author's calculations, using aggregate country-level data for 2016 on the foreign activities of US MNCs from the US Bureau of Economic Analysis (BEA), available at: www.bea.gov. These calculations are based on the BEA's preliminary 2016 data, which may potentially change when revised by the BEA. Tax havens are defined using the classification in Dharmapala and Hines (2009), with some minor updates described in the text. 
Figure 2: The BEA Definition of "Net Income": A Simple Example

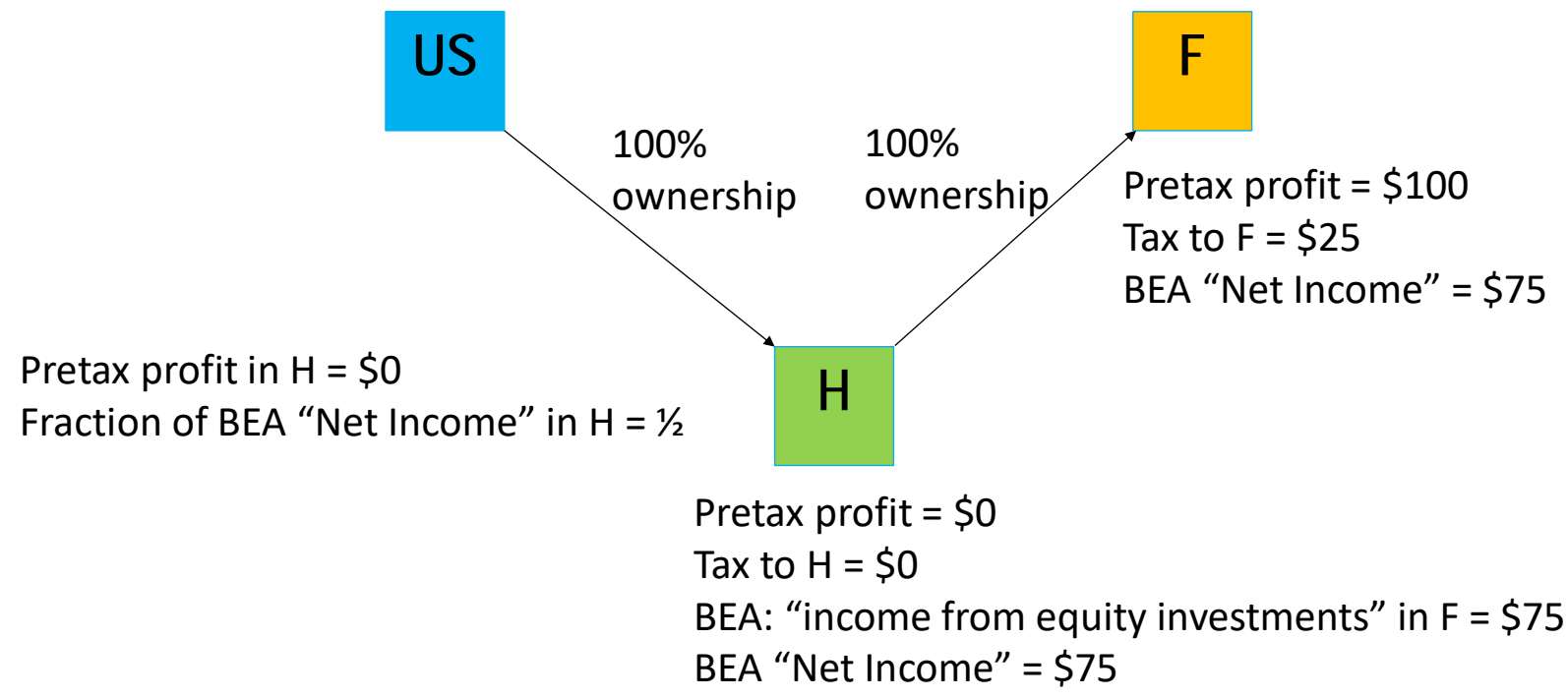

Note: This example illustrates the definition of the concept of "Net Income" reported by the Bureau of Economic Analysis (BEA), based on the discussion in Blouin and Robinson (2019). The US parent firm owns a holding company in a haven $(\mathrm{H})$ and this holding company in turn owns $100 \%$ of an affiliate in a foreign nonhaven country (F) with a $25 \%$ tax rate. The affiliate in $\mathrm{F}$ earns $\$ 100$, pays $\$ 25$ tax to the government of $\mathrm{F}$, and retains the remaining $\$ 75$. The $\mathrm{H}$ affiliate generates no profits and pays zero taxes. Nonetheless, it would be recorded in the BEA data as having "income from equity investments" of $\$ 75$ and therefore Net Income of $\$ 75$. The F affiliate would also be recorded as having Net Income of \$75. 
Figure 3: Haven Jurisdictions' Shares of Selected Types of Income (Majority-Owned Foreign Affiliates of US MNCs, 2014 Benchmark Survey)

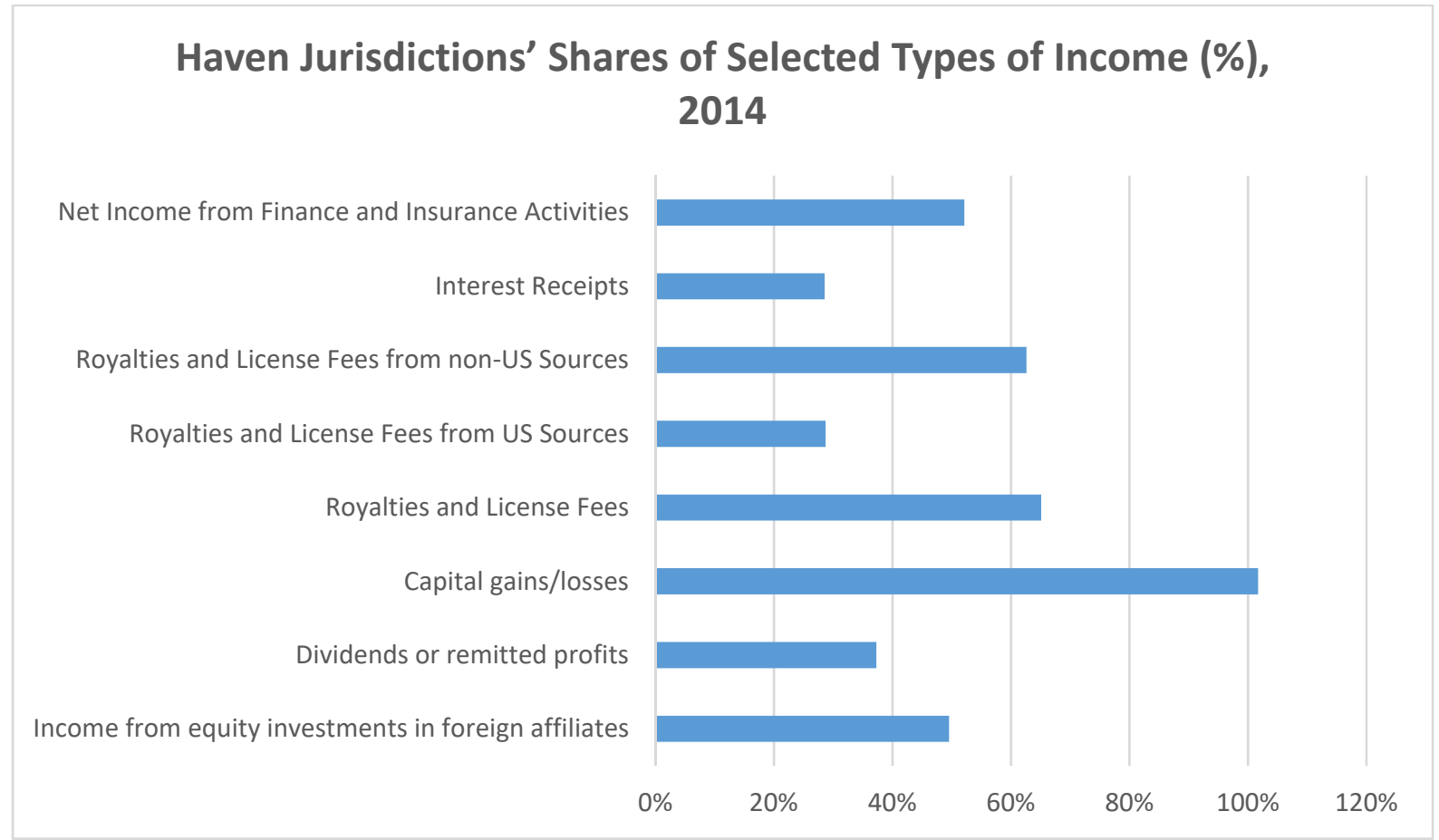

Note: Author's calculations, using aggregate country-level data for 2014 benchmark survey on the foreign activities of US MNCs from the US Bureau of Economic Analysis (BEA), available at: www.bea.gov. The BEA's benchmark surveys provide more detailed information and more extensive coverage than its annual surveys. Tax havens are defined using the classification in Dharmapala and Hines (2009), with some minor updates described in the text. 
Figure 4: Haven Jurisdictions' Shares of Selected Types of Income (Majority-Owned Foreign Affiliates of US MNCs, 2009 Benchmark Survey)

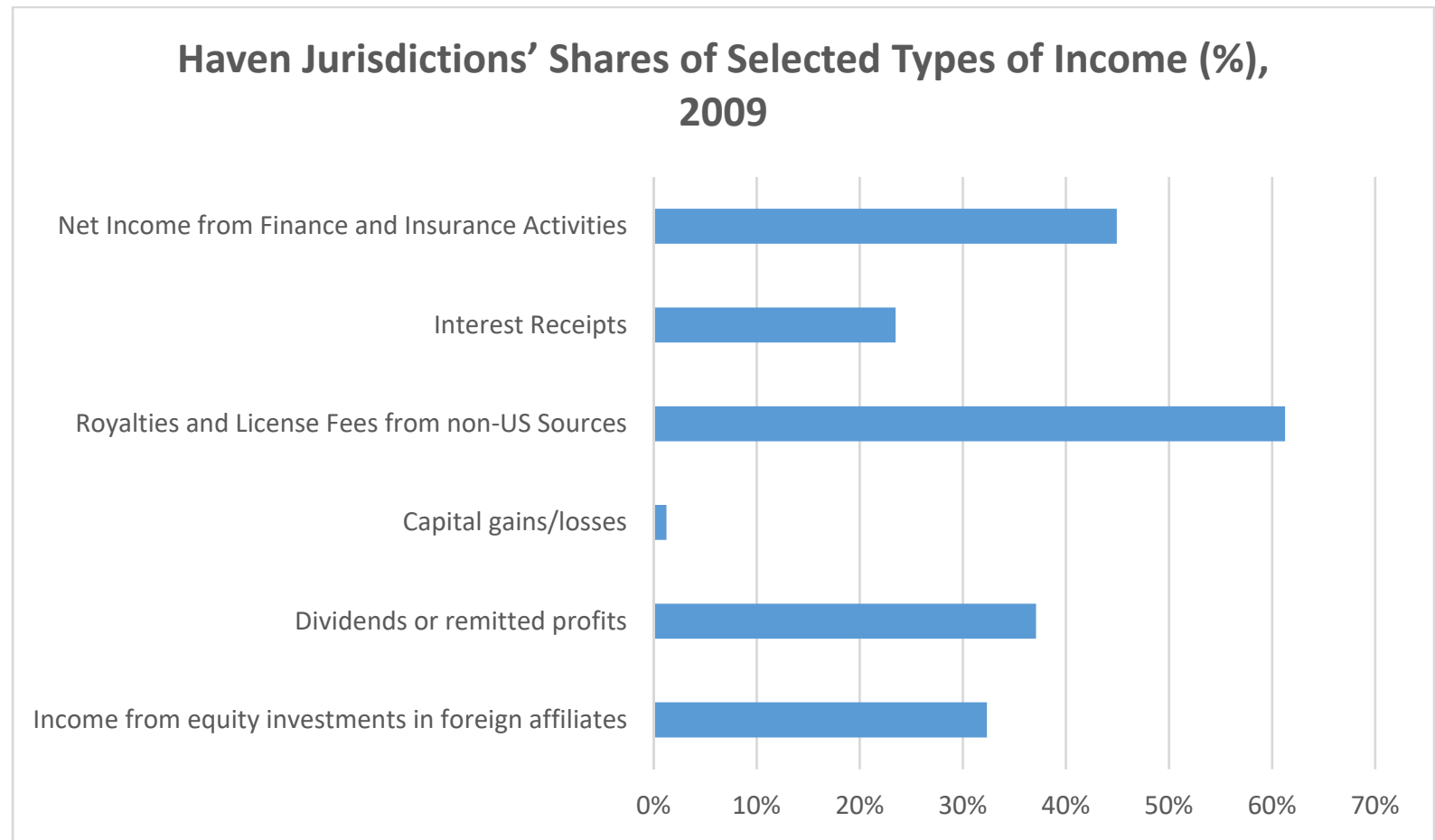

Note: Author's calculations, using aggregate country-level data for 2014 benchmark survey on the foreign activities of US MNCs from the US Bureau of Economic Analysis (BEA), available at: www.bea.gov. The BEA's benchmark surveys provide more detailed information and more extensive coverage than its annual surveys. Note that royalties and license fees from non-US sources are not reported for 2009. Tax havens are defined using the classification in Dharmapala and Hines (2009), with some minor updates described in the text. 
Figure 5: Composition of the Total Income of Haven and Nonhaven Affiliates (MajorityOwned Foreign Affiliates of US MNCs, 2014 Benchmark Survey)

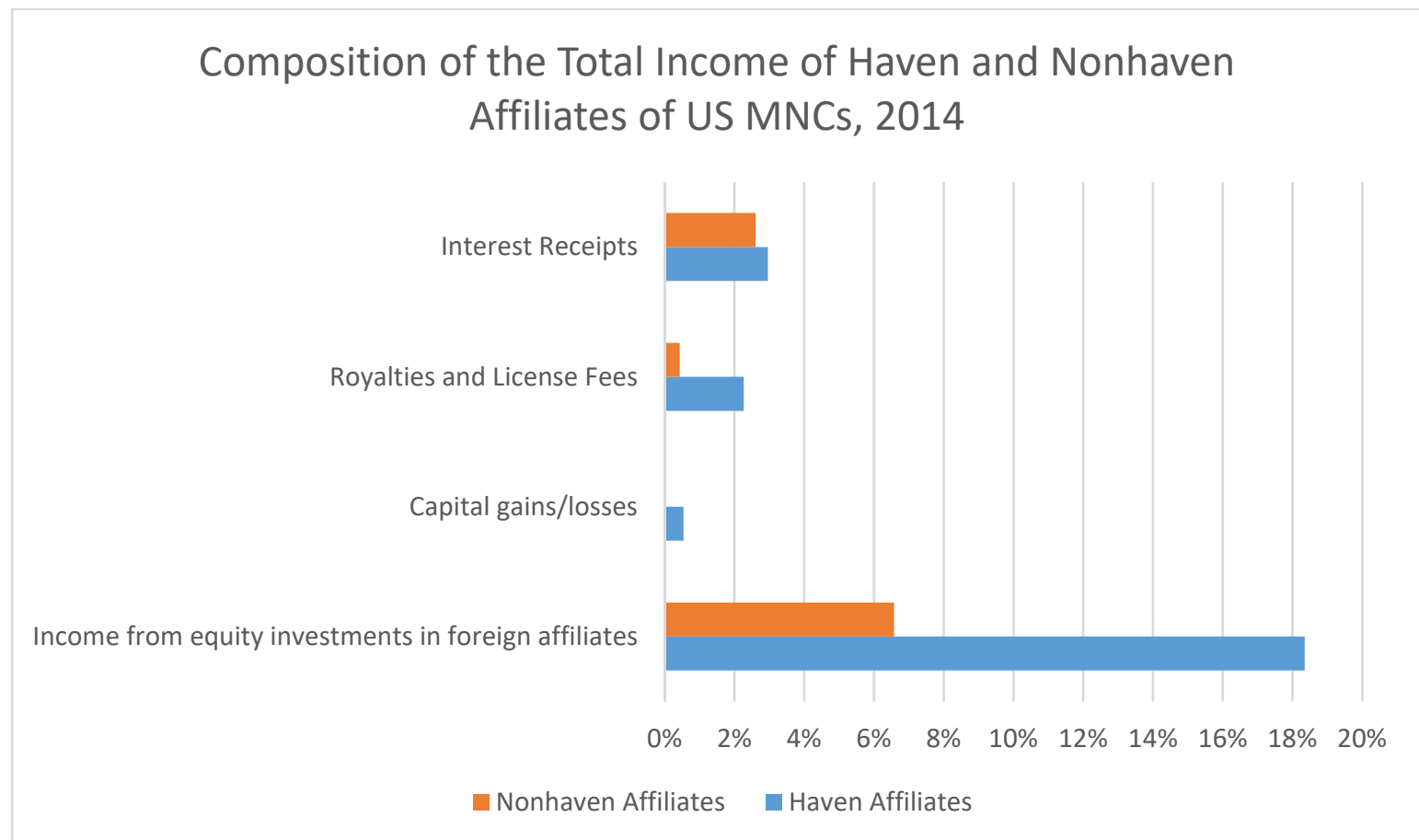

Note: Author's calculations, using aggregate country-level data for the 2014 benchmark survey on the foreign activities of US MNCs from the US Bureau of Economic Analysis (BEA), available at: www.bea.gov. The BEA's benchmark surveys provide more detailed information and more extensive coverage than its annual surveys. Tax havens are defined using the classification in Dharmapala and Hines (2009), with some minor updates described in the text. 
Figure 6: Composition of the Total Income of Haven and Nonhaven Affiliates (MajorityOwned Foreign Affiliates of US MNCs, 2009 Benchmark Survey)

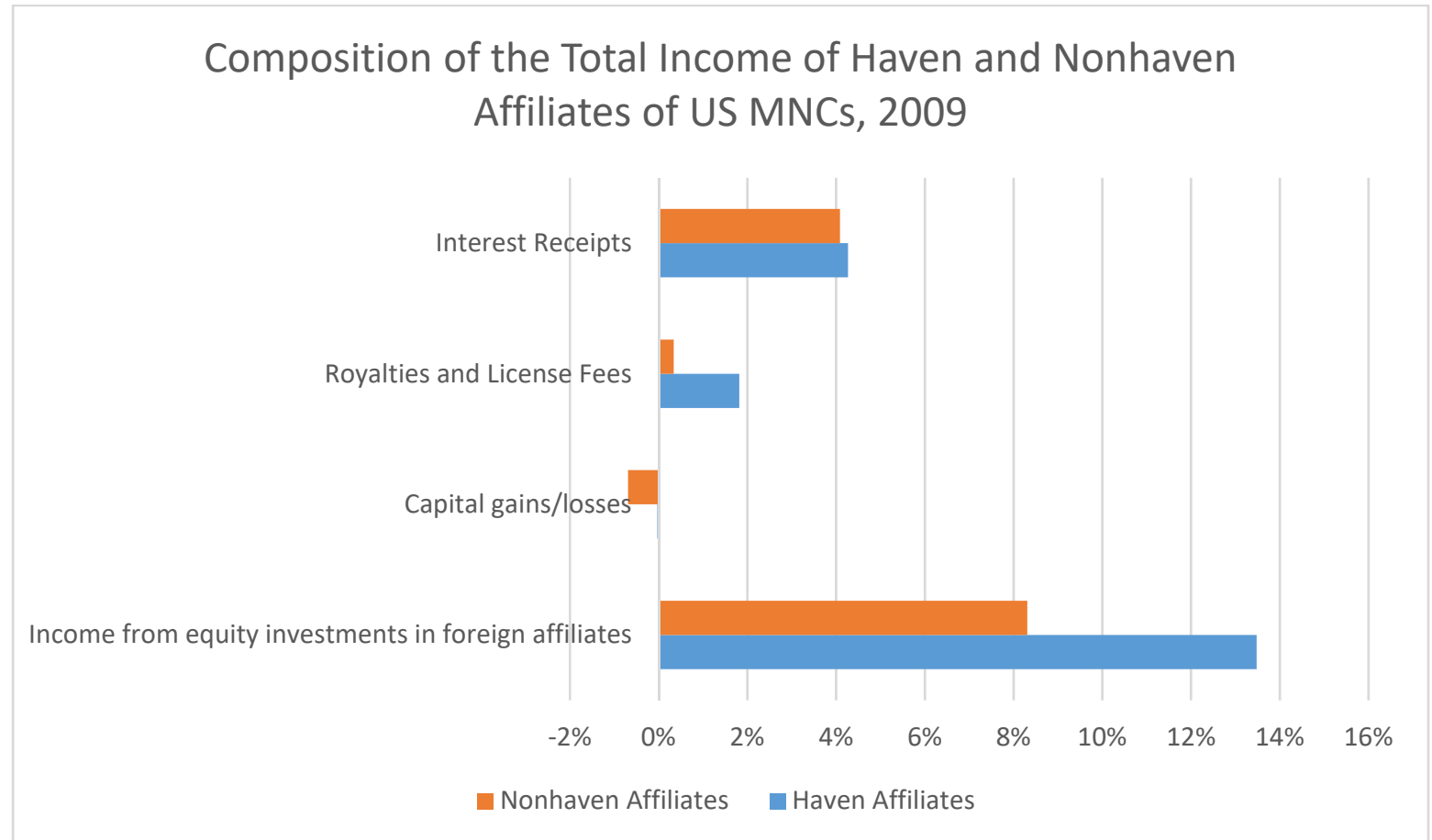

Note: Author's calculations, using aggregate country-level data for the 2009 benchmark survey on the foreign activities of US MNCs from the US Bureau of Economic Analysis (BEA), available at: www.bea.gov. The BEA's benchmark surveys provide more detailed information and more extensive coverage than its annual surveys. Tax havens are defined using the classification in Dharmapala and Hines (2009), with some minor updates described in the text. 
Figure 7: The Share of Net Income from Finance and Insurance Activities for Haven and Nonhaven Affiliates (Majority-Owned Foreign Affiliates of US MNCs, 2014 Benchmark Survey)

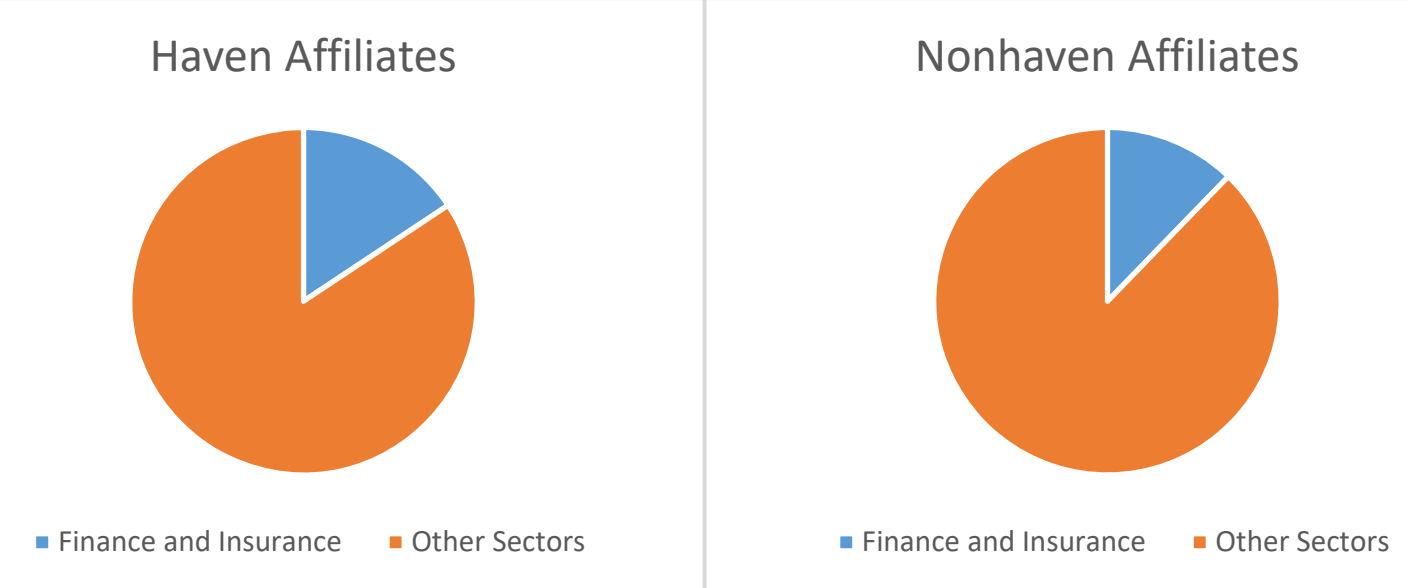

Note: Author's calculations, using aggregate country-level data for the 2014 benchmark survey on the foreign activities of US MNCs from the US Bureau of Economic Analysis (BEA), available at: www.bea.gov. The BEA's benchmark surveys provide more detailed information and more extensive coverage than its annual surveys. Tax havens are defined using the classification in Dharmapala and Hines (2009), with some minor updates described in the text. 
Figure 8: Residence Country (A's) National Welfare with no CFC Rule

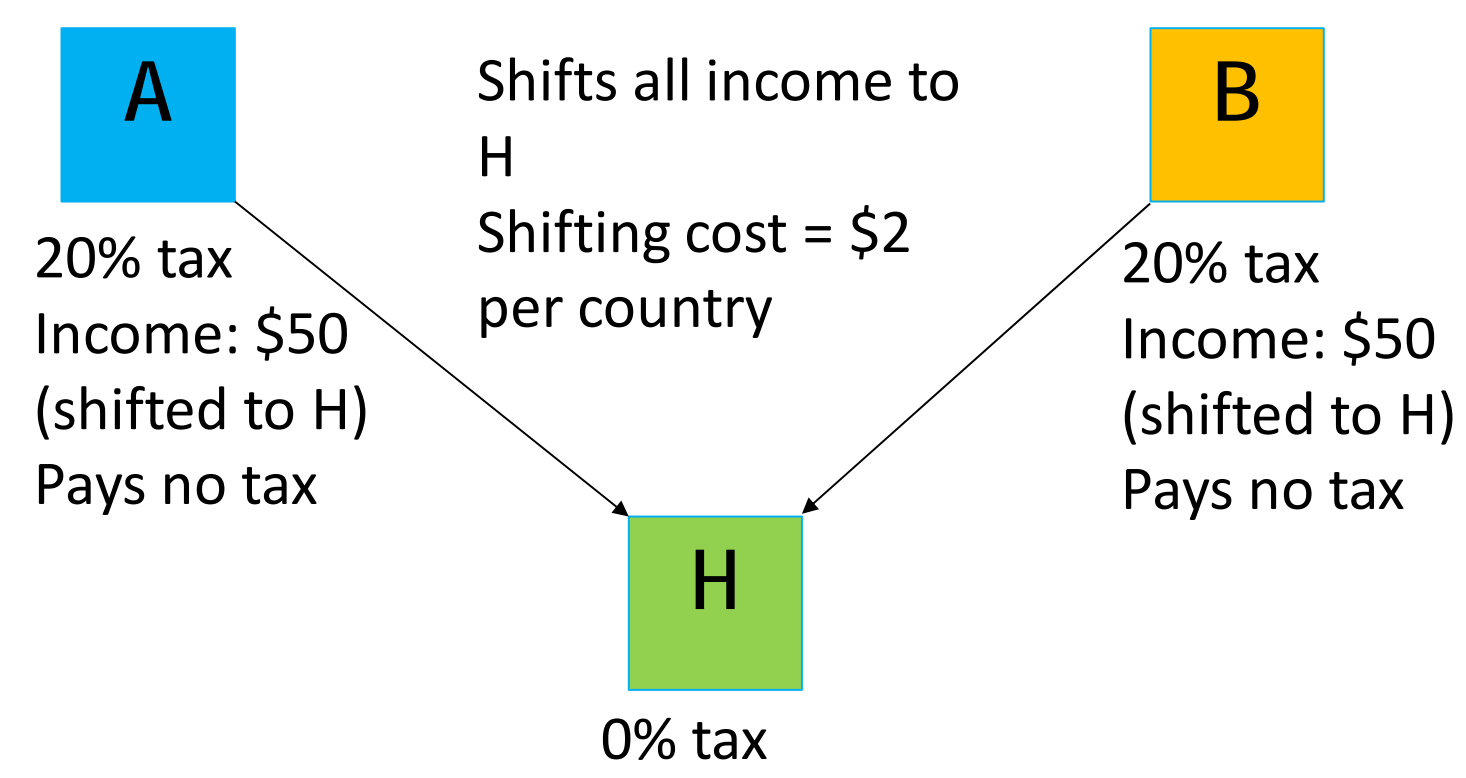

Firm A's payoff $=\$ 96$

Earnings: $\$ 100$

\section{Country A's national welfare $=\$ 96$}

Note: When country A does not impose a CFC rule, Firm A will shift all of its profits from both $A$ and $B$ to the haven $H$ (thereby saving $\$ 10$ of tax in each of $A$ and $B$, and incurring a $\$ 2$ cost of tax planning in each country). Firm A's profits, taking account of the $\$ 4$ cost of profit shifting, will be $\$ 96$ and country A's revenue will be zero (so that the national welfare of country A is $\$ 96$ ). 
Figure 9: Residence Country (A's) National Welfare with a CFC Rule

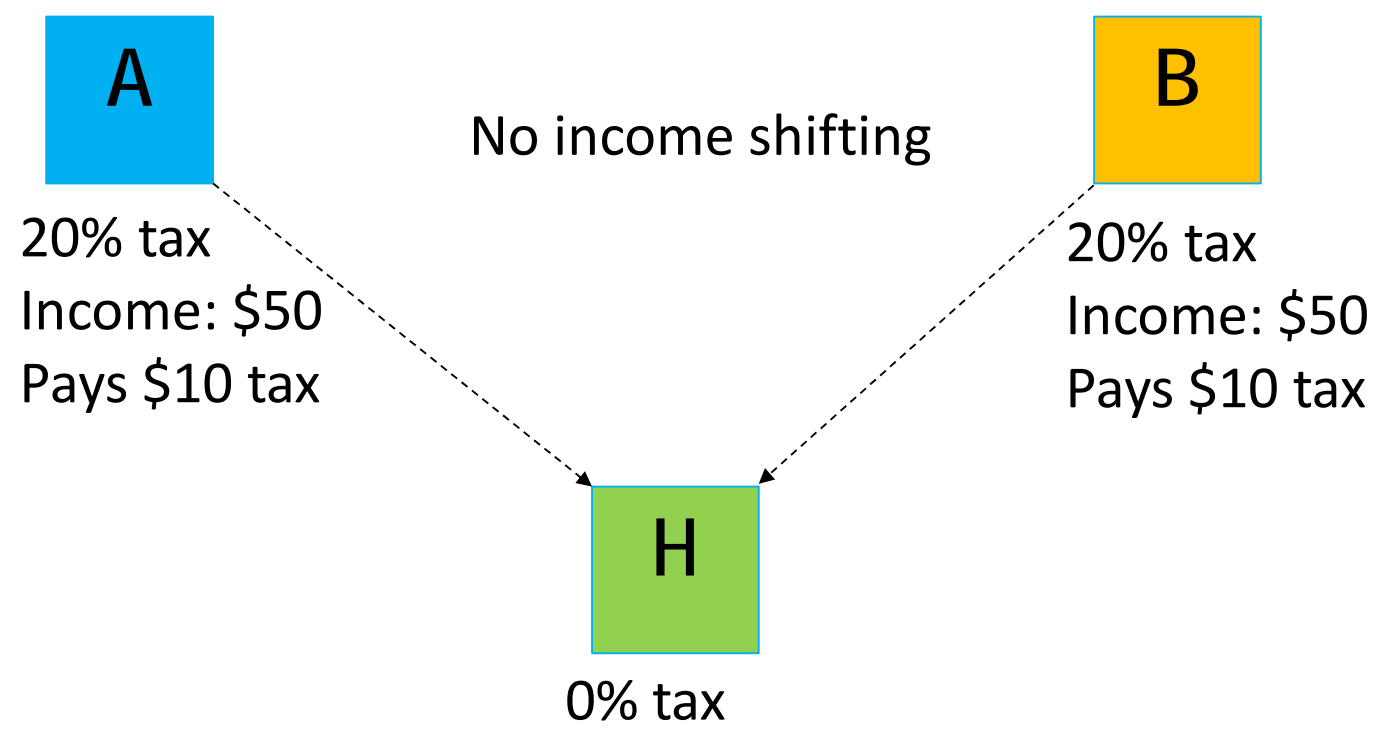

Firm A's payoff $=\$ 80$

Earnings: \$0

Country A's national welfare $=\$ 90$ ( $\downarrow$ due to increased foreign tax payments)

Note: Firm A no longer shifts profits from either A or B to the haven $\mathrm{H}$, as doing so would result in the income reported in $\mathrm{H}$ being taxed at country A's $20 \%$ tax rate, while Firm A would also incur a $\$ 4$ cost of tax planning. Firm A pays $\$ 10$ of tax to each of governments $A$ and $B$, and has after-tax profits of $\$ 80$. The government of country A raises $\$ 10$ of revenue, so country A's national welfare is $\$ 90$. 
Pre-CTB: Income shifted from $\mathrm{B}$ to $\mathrm{H}$ taxed by the US under Subpart $F$ Post-CTB: MNC can elect to treat $\mathrm{H}$ affiliate as a branch of affiliate $B$ for US tax purposes, avoiding Subpart $F$

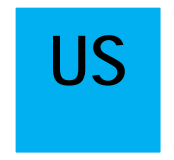

Note: Firm A elects (for US tax purposes) to have the haven affiliate H treated as an unincorporated branch of the $\mathrm{B}$ affiliate. The passive income received by the $\mathrm{H}$ affiliate is invisible to the US tax system (the box outlined by dashed lines indicates the entity that is perceived by the US). At the same time, the haven affiliate is a separately incorporated entity from the B affiliate under the tax laws of country B (thus enabling, for instance, interest or other payments paid from $\mathrm{B}$ to $\mathrm{H}$ to be deductible in country B). 
Figure 11: Thin Capitalization (Earnings Stripping) Rule

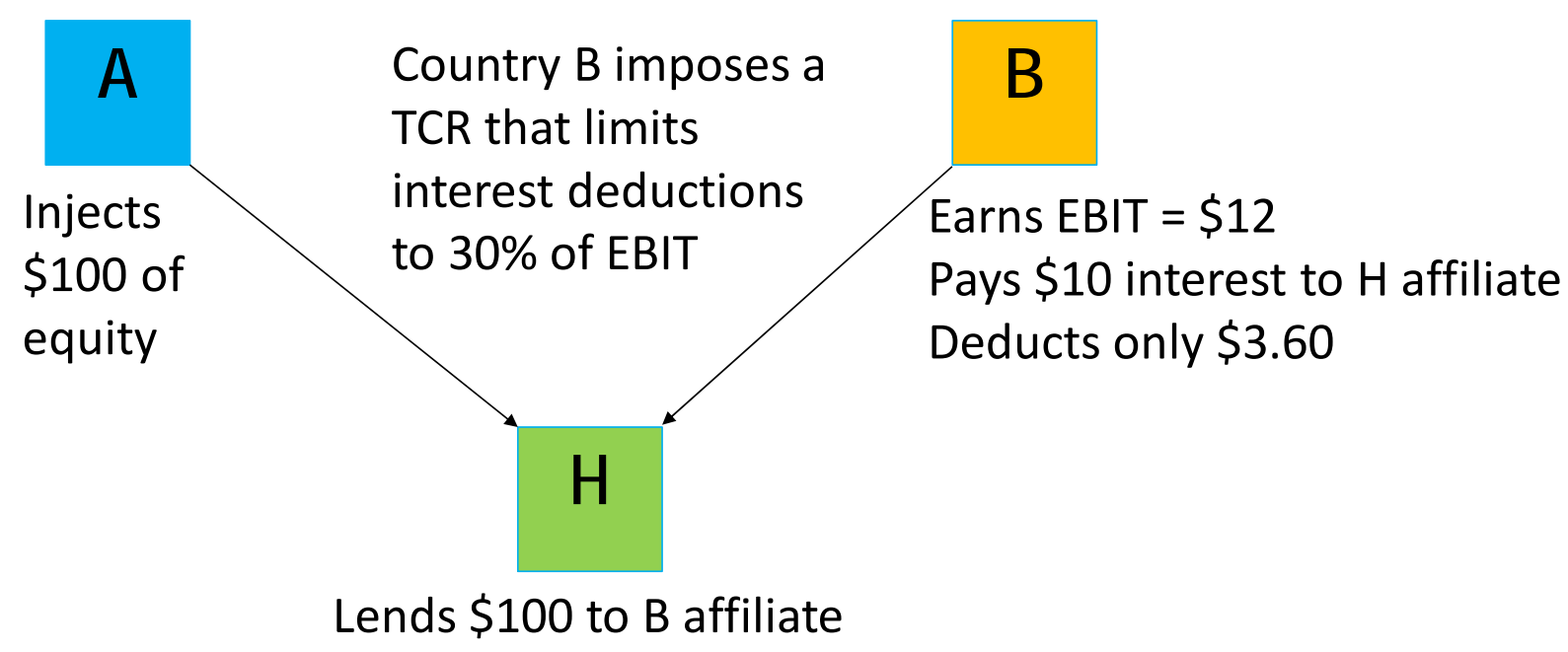

Note: Firm A injects $\$ 100$ of equity into its haven affiliate $H$, which then lends this $\$ 100$ to Firm A's affiliate in country B. Suppose that the (arm's length) interest rate is $10 \%$. In the absence of a TCR, affiliate B would be able to deduct $\$ 10$ of interest in country B. With B's TCR, affiliate B's interest deductions are constrained. Assume that EBIT for affiliate B is $\$ 12$; then, interest deductions are limited to $\$ 3.60$. Country B's TCR thus limits the profit shifted from B to $H$ to $\$ 3.60$, rather than the $\$ 10$ that could be shifted absent the TCR. 
Figure 12: Minimum Tax Rate on Foreign Passive Income Implied by the CFC Rules of OECD Countries, 2000 and 2014

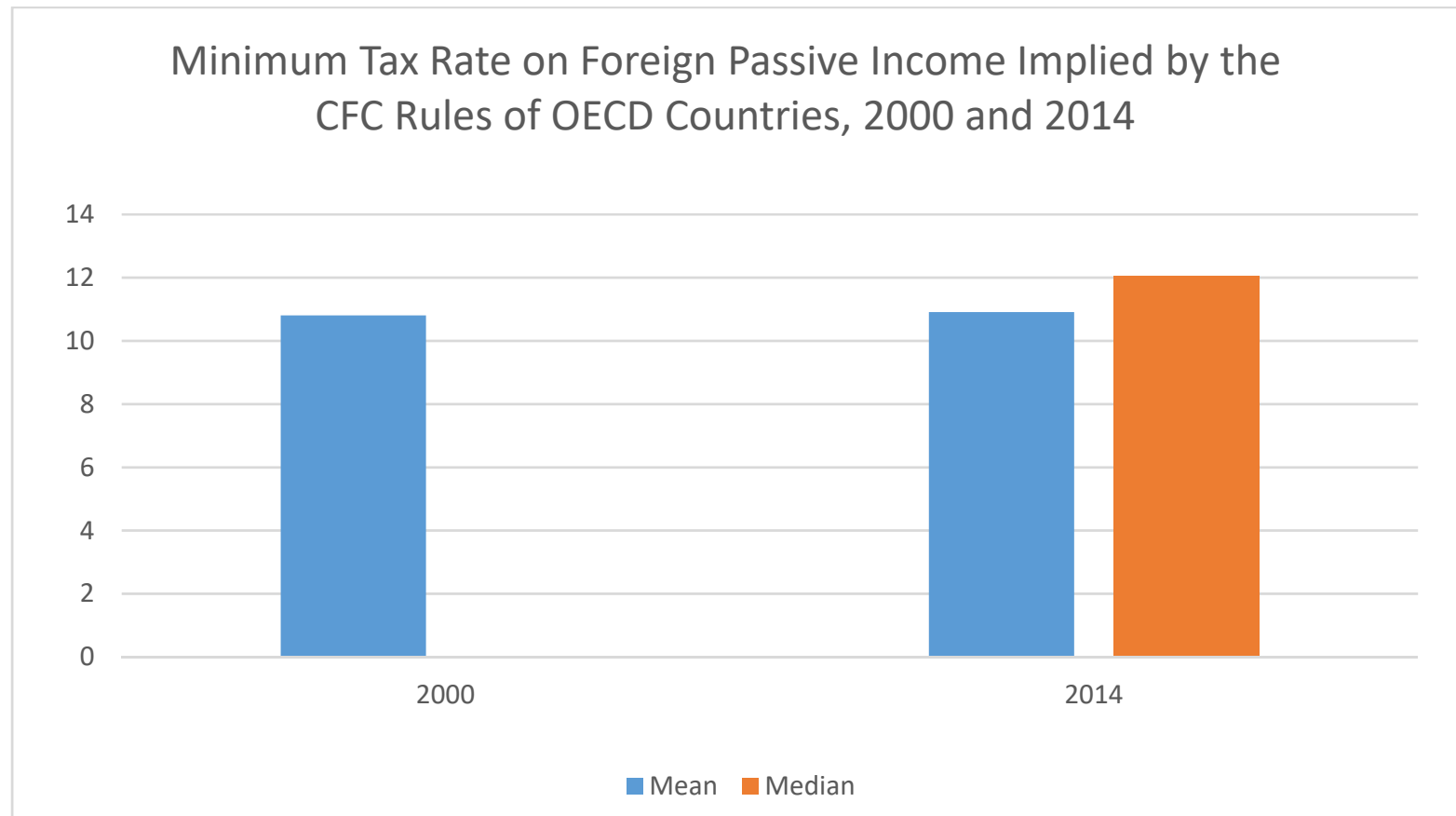

Source: Author's calculations, using the dataset on CFC rules constructed and described in Dharmapala (2019). Note that the median in 2000 was zero. 
Figure 13: Ratio of the Minimum Tax Rate on Foreign Passive Income to the Corporate Income Tax Rate, as Implied by the CFC Rules of OECD Countries, 2000 and 2014

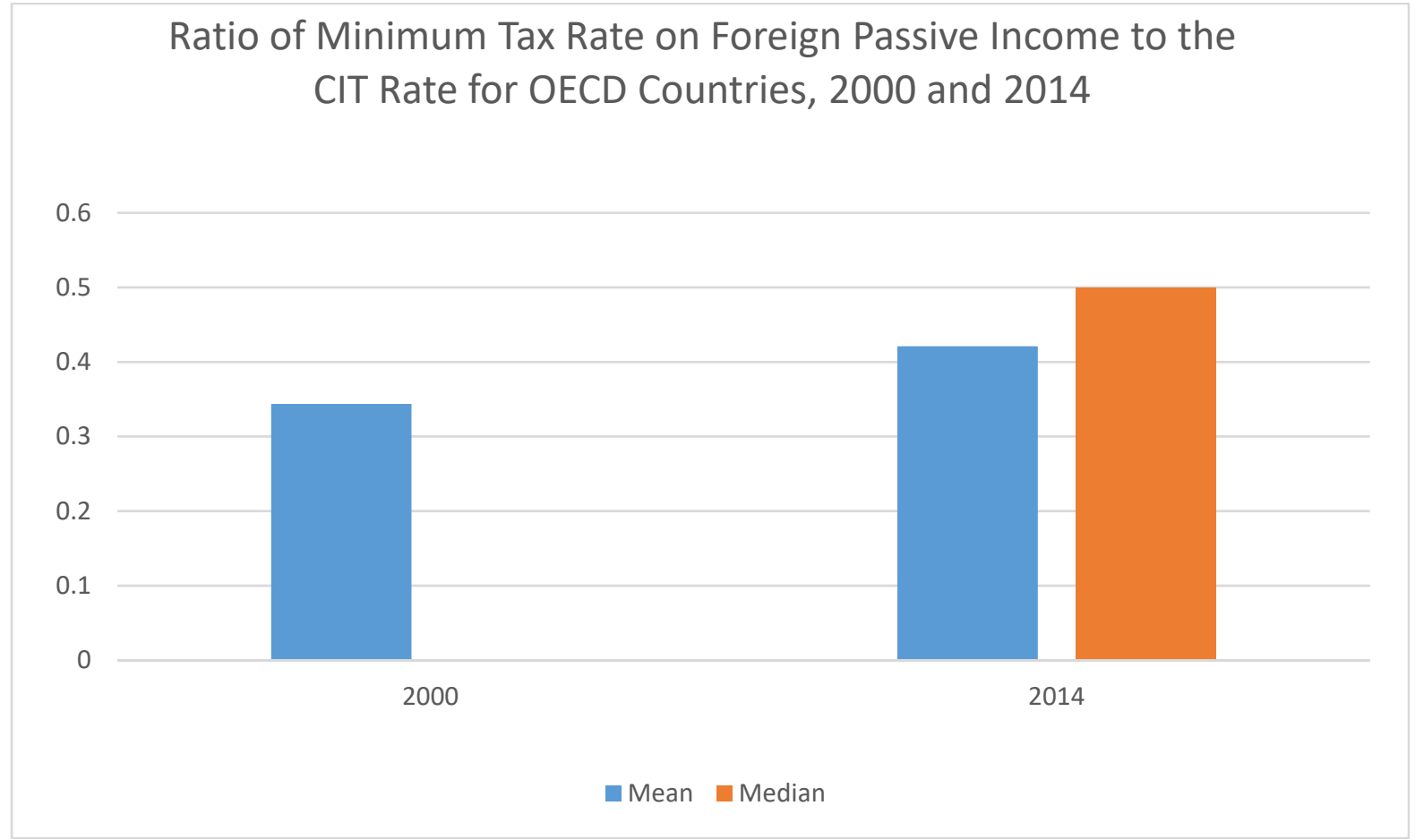

Source: Based on Dharmapala (2019, Figure 1). Note that the median in 2000 was zero. 
Figure 14: Ratio of the Minimum Tax Rate on Foreign Passive Income to the Corporate Income Tax Rate, as Implied by the CFC Rules of OECD Countries, 2000 and 2014

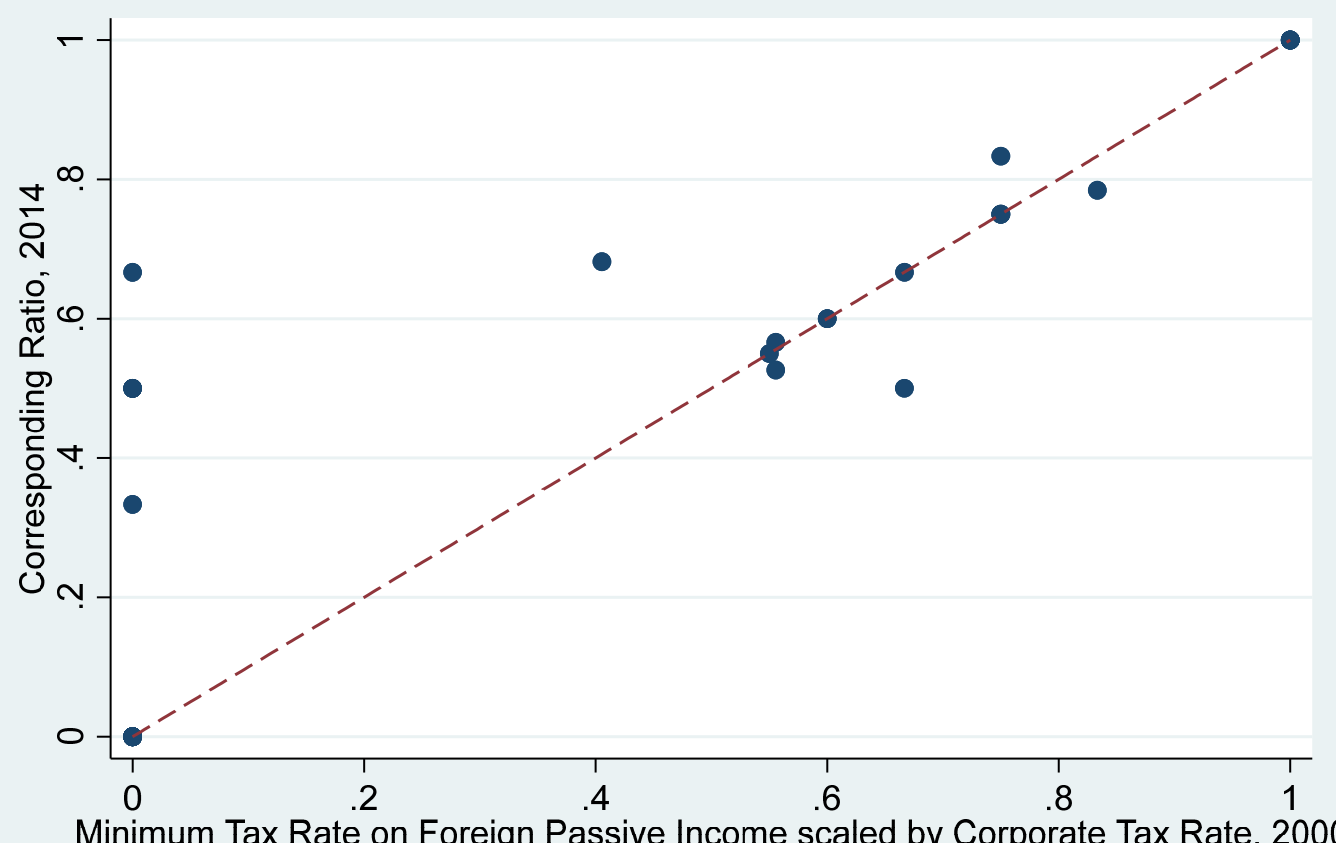

- Observations, OECD countries - - - - Equality

Source: Author's calculations, using the dataset on CFC rules constructed and described in Dharmapala (2019). 
Figure 15: Thin Capitalization Rules in OECD Countries, 2000 and 2014

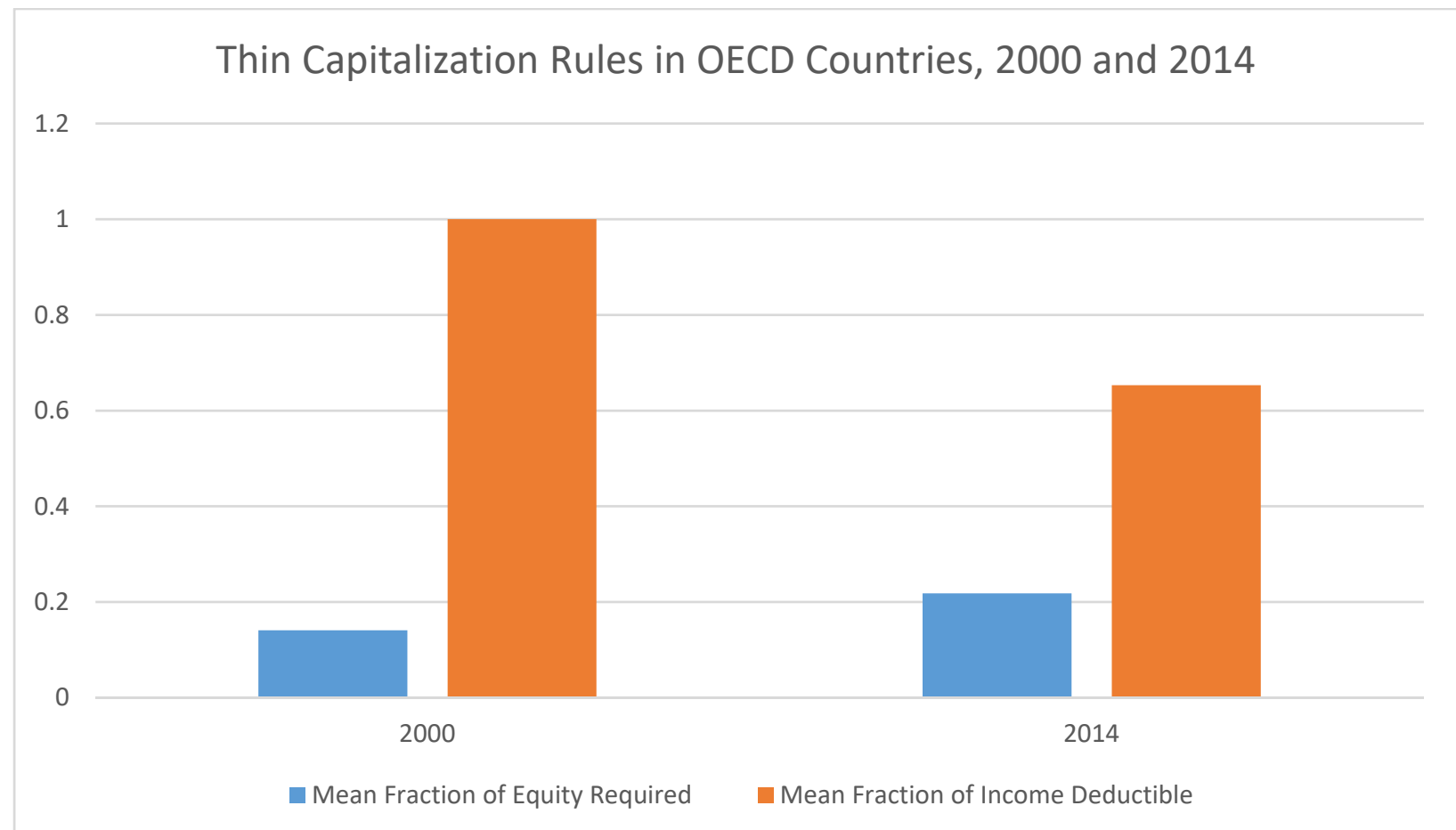

Source: Based on Dharmapala (2019, Figure 2).

Figure 16: Tax Avoidance versus Behavioral Responses

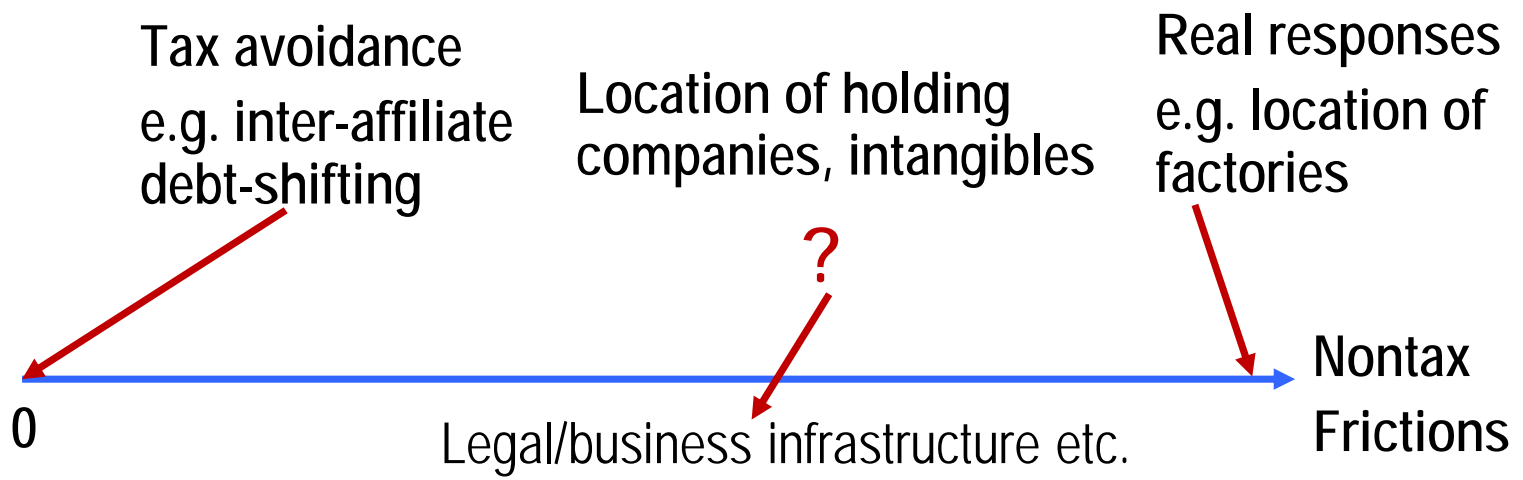

Note: This figure illustrates the difference between tax avoidance and behavioral responses to taxation. Nontax frictions are increasing along the axis towards the right. When nontax frictions do not exist, taxpayers' responses to taxes are classified as forms of tax avoidance. As nontax frictions become larger, taxpayers' responses to taxes are classified as behavioral (or real) responses. 